University of Nebraska - Lincoln

DigitalCommons@University of Nebraska - Lincoln

1996

\title{
Stress perturbation associated with the Amazonas and other ancient continental rifts
}

Mary Lou Zoback

U.S. Geological Survey, marylouz@stanford.edu

Randall M. Richardson

University of Arizona

Follow this and additional works at: https://digitalcommons.unl.edu/usgsstaffpub

Part of the Earth Sciences Commons

Zoback, Mary Lou and Richardson, Randall M., "Stress perturbation associated with the Amazonas and other ancient continental rifts" (1996). USGS Staff -- Published Research. 465.

https://digitalcommons.unl.edu/usgsstaffpub/465

This Article is brought to you for free and open access by the US Geological Survey at DigitalCommons@University of Nebraska - Lincoln. It has been accepted for inclusion in USGS Staff -- Published Research by an authorized administrator of DigitalCommons@University of Nebraska - Lincoln. 


\title{
Stress perturbation associated with the Amazonas and other ancient continental rifts
}

\author{
Mary Lou Zoback \\ Branch of Seismology, U.S. Geological Survey, Menlo Park, California \\ Randall M. Richardson \\ Southern Arizona Seismic Observatory. Department of Geosciences, University of Arizona. Tucson
}

\begin{abstract}
The state of stress in the vicinity of old continental rifts is examined to investigate the possibility that crustal structure associated with ancient rifts (specifically a dense rift pillow in the lower crust) may modify substantially the regional stress field. Both shallow (2.0-2.6 km depth) breakout data and deep (20-45 km depth) crustal earthquake focal mechanisms indicate a N to NNE maximum horizontal compression in the vicinity of the Paleozoic Amazonas rift in central Brazil. This compressive stress direction is nearly perpendicular to the rift structure and represents a $\sim 75^{\circ}$ rotation relative to a regional $\mathrm{E}-\mathrm{W}$ compressive stress direction in the South American plate. Elastic two-dimensional finite element models of the density structure associated with the Amazonas rift (as inferred from independent gravity modeling) indicate that elastic support of this dense feature would generate horizontal rift-normal compressional stresses between 60 and 120 $\mathrm{MPa}$, with values of 80-100 MPa probably most representative of the overall structure. The observed $\sim 75^{\circ}$ stress rotation constrains the ratio of the regional horizontal stress difference to the rift-normal compressive stress to be between 0.25 and 1.0 , suggesting that this rift-normal stress may be from 1 to 4 times larger than the regional horizontal stress difference. A general expression for the modification of the normalized local horizontal shear stress (relative to the regional horizontal shear stress) shows that the same ratio of the rift-normal compression relative to the regional horizontal stress difference, which controls the amount of stress rotation, also determines whether the superposed stress increases or decreases the local maximum horizontal shear stress. The potential for fault reactivation of ancient continental rifts in general is analyzed considering both the local stress rotation and modification of horizontal shear stress for both thrust and strike-slip stress regimes. In the Amazonas rift case, because the observed stress rotation only weakly constrains the ratio of the regional horizontal stress difference to the rift-normal compression to be between 0.25 and 1.0 , our analysis is inconclusive because the resultant normalized horizontal shear stress may be reduced (for ratios $>0.5$ ) or enhanced (for ratios $<0.5$ ). Additional information is needed on all three stress magnitudes to predict how a change in horizontal shear stress directly influences the likelihood of faulting in the thrust-faulting stress regime in the vicinity of the Amazonas rift. A rift-normal stress associated with the seismically active New Madrid ancient rift may be sufficient to rotate the horizontal stress field consistent with strike-slip faults parallel to the axis of the rift. although this results in a $20-40 \%$ reduction in the local horizontal shear stress within the seismic zone. Sparse stress data in the vicinity of the seismically quiescent Midcontinent rift of the central United States suggest a stress state similar to that of New Madrid, with the local horizontal shear stress potentially reduced by as much as $60 \%$. Thus the markedly different levels of seismic activity associated with these two subparallel ancient rifts is probably due to other factors than stress perturbations due to dense rift pillows. The modeling and analysis here demonstrate that rift-normal compressive stresses are a significant source of stress acting on the lithosphere and that in some cases may be a contributing factor to the association of intraplate seismicity with old zones of continental extension.
\end{abstract}

\section{Introduction}

Analyses of tectonic correlations in regions of intraplate seismicity invariably show a correlation with "ancient continental rift zones" or other crustal zones with a history of exten-

Copyright 1996 by the American Geophysical Union.

Paper number 95JB03256.

$11148-(1) 227 / 96 / 45 \mathrm{JB}-(132356 \$ 05.01)$ sional tectonics [Bashum, 1989; Johnston, 1989; Johnston and Kantor, 1999); Mitchell et al., 1991]. This correlation between rift zones and intraplate seismicity is commonly attributed to reactivation of "preexisting zones of weahness" associated with rifting. An idditional possibility is that crustal structure associated with ancient rifts may actually modify the regional stress field and increase the likelihood of lailure. Seismic refraction investigations commonly indicate the presence of a high- 
density lower crustal hody $(1, \mu=7.2-7.5 \mathrm{~km} / \mathrm{s}, \rho=3000-$ $3 l(x) \mathrm{kg} \mathrm{m}^{3}$ ) hencath both some nodern and most ancient continental rifts [1/eoney of al. 1983]. This so called "rift pillow:" with a P wase velocity intermediate between normal lower crustal and upper mantle velocities, probably represents matic magmatic intrusion into the lower crust during rift formation. In ancient (fatled) rilts the excess mass of the pillow is frozen into the lower erust and must be supported by the strength of the cooled lithosphere, inducing deviatoric stresses in the plate. The induced stress cunsists of hending stresses, which are likely to dominate, and isostatic buoyancy stresses associated with deflected density interfaces. Support of the rift pillow should cause compression perpendicular to the rift in the upper part of the lithosphere.

The Paleozoic Amazonas rift in central Brazil appears to be an example of an ancient rift which is significantly modifying the current regional stress field, causing a roughly $90^{\circ}$ rotation of the horizontal stresses. This "rotated" local stress field appears to have generated two moderate-sized $\left(m_{h}=5.1\right.$ and $5.5)$ intraplate thrust events in the last 30 years. The purpose of the Amazonas rift modeling in this paper is to establish that buried loads can generate significant stresses perpendicular to the rift axis. The results are used to evaluate active seismic deformation in terms of the superposition of the "rift pillow" stresses on the regional tectonic stress field in the South American plate. Finally, we generalize the stress effect of a dense rift pillow on both stress urientation and relative magnitude, then apply the results to two additional ancient continental rifts in the North American plate, the New Madrid (Reelfoot) and Midcontinent rifts.

\section{Regional Stress Field and Tectonic Setting of the Amazonas Rift}

Figure 1 shows maximum horizontal stress $\left(S_{H_{\text {nus }}}\right)$ orientations for the northern part of the South American plate determined from earthquake focal mechanisms, well bore breakouts, and fault slip data [-Assumpşão, 1992; Mercier et al., 1992]. The data shown are trom the World Stress Map database [Zoback, 1992] supplemented with sume new focal mechanism solutions [Assumps'üo and Araujo. 1993; .Assumpção, 1994; Ferreira et al.. 1994: Velose et al., 1994]. The data (particularly focal mechanism data between $15^{\circ} \mathrm{S}$ and $25^{\circ} \mathrm{S}$ ) suggest that an E-W $S_{H_{n,}}$ direction appears to dominate the continental portion of the South American plate (including the high Andes), with the possible exception of the Atlantic coastal region and central Brazil. Stress perturbation in the coastal region may be related to passive margin normal extensional stresses due to the extremely steep continental slope [.Asstmpgräo, 1992]. As seen in Figure 1, the stress regime in the high Andes is extensional (N-S extension, E-W $S_{H_{\text {int }}}$ ), whereas deformation in the rest of the plate is dominantly compressional, as indicated by primarily thrust and a feu strike-slip carthquakes.

The E-W compressive stress regime in the interior of the South American plate eatn he explained as a result of plate driving forces acting on the geometry of the plate. Ridge push forees, absolute plate motion (which may result in basal drag forces), and convergent forces along the western margin all trend approximatcly E-W [e.g.. .Assum/ķäo, 1992]. Sitefanick and Jurdy [1992] modeled the stress field within the South American plate and determined that the obsened stress orientations were best matched by models incorporating ridge push, minor slath pull at the Scotia and Caribhean ares (south and north boundaries of plate), and trench suction near th: western coast. balanced by plate drag. Meijer and Wortel [1992] considering only torques and not stresses, concluded that basil drag could play a role in addition to ridge and other forces acting on the South American plate. The stress indicators for the Andean region have a very uniform E-W orientation, even, in the presence of several potential perturbing factors such w the variable strike of the Andean range, segmentation of the underlying subducted lithosphere, and the subduction of asew. mic ridges [Assumpção, 1992]. Richardson and Coblentz [1944] have used the uniform E-W $S_{H_{\text {max }}}$ orientation to argue for $d$ distant process origin for the Andean stress field, such as ridg. push.

In the context of the predicted long-wavelength E-W compressive stress ficld in the South American plate, it is intereying to note the approximately $90^{\circ}$ rotation of stress orientation. in central Brazil from both well bore breakout analysis and earthquake focal mechanisms (Figure 1). This rotation occurs in the vicinity of the Amazonas rift, which is believed to haw formed in response to a continental rifting event which $x$. curred between Ordovician and Permian time (505-245 Ma [Numn and Aires, 1988]. Transecting the South American craton, this roughly E-W trending rift zone is one of the world: largest continental rifts; its rift basin controls the present-da! drainage of the Amazon River.

Both the earthquake focal mechanisms and well bore bre.lkouts in the vicinity of the rift consistently indicate $\mathrm{N}$ to NNE $S_{H_{\text {max }}}$ orientations, despite the very different depth interval sampled by these two stress indicators. The two available focil mechanisms are shown on Figure 1; both show nearly purc thrust or reverse faulting on approximately E-W trending planes, implying an approximately N-S $S_{H_{i n s}}$ orientation (December $14,1963, m_{h}=5.1$, azimuth/plunge of $P$ axis $=$ $14^{\circ} / 10^{\circ}$ and $T$ axis $=264^{\circ} / 62^{\circ}$ : August 5, 1983, $m_{h}=5.5$. azimuth/plunge of $P$ axis $=329^{\circ} / 7^{\circ}$ and $T$ axis $=184^{\circ} \mathrm{sz}$ : [Assumpşão and Suarez, 1988]. Both events occurred along th. northern margin of the Amazonas rift and are anomalous! deep ( $23 \mathrm{~km}$ and $45 \mathrm{~km}$. respectively) for intraplate seismicin Analysis of breakouts from four petroleum exploration wells $t$ the west within the overlying basin sediments (depth range of $2.0-2.6 \mathrm{~km}$ ) yield a mean $S_{H_{\text {mlut }}}$ orientation of $\mathrm{N} 15^{\circ} \pm 1 \mathrm{WE}$ [Weller, 1993] (Table 1). suggesting that this approximately N-S maximum horizontal compressional stress occurs throughout the entire brittle crust. An additional NNE $S_{n_{\text {mans }}}$ orientiation was inferred from breakouts in the Potiguar basin north of thi Amazonas rift [Cox, 1983, also written communication, 14st] The analysis was done during a tield visit; a total of 35 bre:uh. outs were measured, but there is no record of whether th' information comes from a single or multiple wells, or hir representative it is of the basin in general.

Perhaps the most striking geophysical characteristic of the Amazonas rift is a chain of Bouguer gravity highs (approwmately +40 to $+90 \mathrm{mGal}$ ) which roughly coincide with the itl" of maximum sediment thickness [Nunn und Aires, 1985]. Th: gravity highs are flanked on either side by gravity low- in approximately $-40 \mathrm{mGal}$. Nunn and Aires [1988] modelud the observed gravity and demonstrated that the large gravity high could be explained by a steep-sided zone of high density in the lower crust varying from 100 to $200 \mathrm{~km}$ in width. The flank in: lows were related to the much broader rift basin fill and thi effects of crustal downwarping. Numn and Aires [1988] ant cluded that in this region the lower continental erust had hest? 


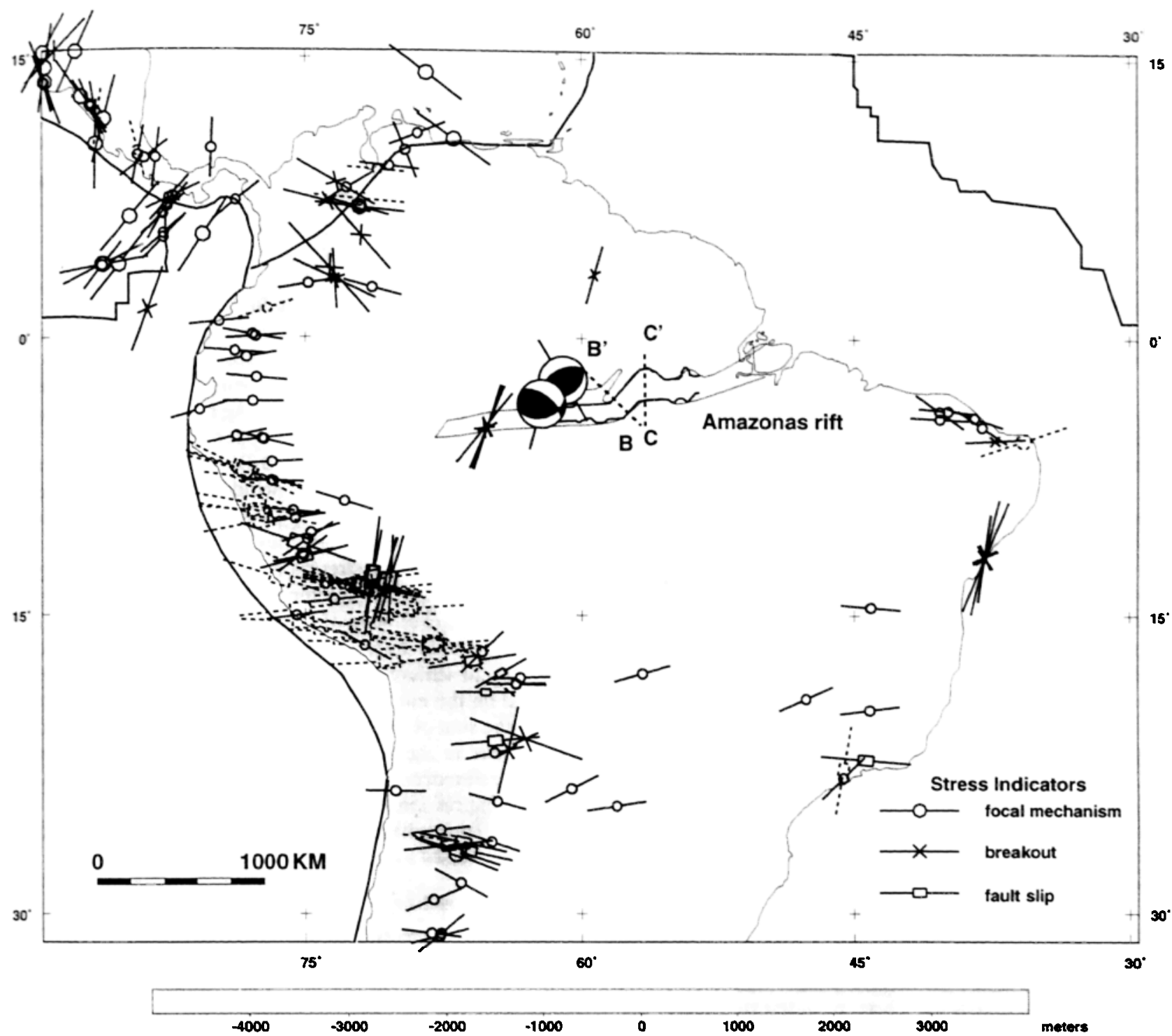

Figure 1. Stress map of northern South America plotted on a base of average topography showing maximum horizontal stress directions from the World Stress Map database and focal mechanisms for central Brazil earthquakes (see text for references). Stress orientations indicating an extensional stress region are plotted with dashed lines; data indicating a strike-slip or thrust stress regime are shou $n$ as solid lines. Linc lengths of stress data are proportional to quality (A-C data plotted; see Zohack [1992] for description of quality ranking). The Amazonas rift hasin is outlined in a thin line, and the modeled portion of the underlying rift pillow is indicated by thick black lines. Dashed lines labeled $B, B^{\prime}$ and $C, C^{\prime}$ indicate the location of the profiles used in the finite element modeling.

intruded/replaced by more dense material to more than half its original thickness of $45-50 \mathrm{~km}$.

The high-density, lower crustal rift pillow probably initially formed beneath the Amazonas rift during the rifting episode when it was isostatically balanced (at least in part) by thinned mantle lithosphere. After rifting ended, the lithosphere gradually cooled and thickened; the load of the rift pillow must then have been statically supported by the bending strength of the lithosphere and, in fact, could have contributed to postrift subsidence. The superposition of a local source of stress duc to the rift pillow upon a regional stress field may also be important for rotating principal stresses [e.g.. Sonder, 1991; Zoback. 1992].

\section{Modeling of the Rift Pillow Stress Effect}

We used purely elastic two-dimensional tinite element modeling to estimate the lecal stress caused by body forces associated with the high-density rift pillow. In our companion paper [(irand and Ruchardsem, this issue] we extend the modeling of continental rifts by incorporating a fully viscoelastic theology (both linear and nonlinear) for models of the stresses derived from a rift pillow for the inferred Precambrian rift underlying the New Madrid seismic zone. The primary difference between the viscoelastic and elastic models is the degree to which stresses are transferred from weak to strong layers, changing the thickness of layers supporting hending stresses. In this 
Table 1. Maximum Horizontal Stress Orientations Determined From Breakouts in the Amazonas Basin

\begin{tabular}{lccccc}
\hline Well Name & $\begin{array}{c}\text { Latifude, } \\
\text { deg }\end{array}$ & $\begin{array}{c}\text { Longitude. } \\
\text { deg }\end{array}$ & $\begin{array}{c}S_{H_{\text {max }}} \text { and Standard } \\
\text { Deviation }\end{array}$ & $\begin{array}{c}\text { Top Breakout } \\
\text { Interval, m }\end{array}$ & $\begin{array}{c}\text { Bottom } \\
\text { Interval, } m\end{array}$ \\
\hline LUC-4-AM & -4.873 & -65.132 & $18^{\circ} \pm 9^{\circ}$ & 2100 & 2390 \\
LUC-5-AM & -4.872 & -65.111 & $20^{\circ} \pm 7^{\circ}$ & 2100 & 200 \\
LUC-7-AM & -4.871 & -65.143 & $23^{\circ} \pm 6^{\circ}$ & 2360 \\
RUC-5-AM & -4.911 & -65.292 & $39^{\circ} \pm 8^{\circ}$ & 230 & 2410 \\
\hline
\end{tabular}

From Weller [1993].

paper the principal objective is to show that stresses associated with the rift pillow are potentially as large as regional stresses due to plate tectonic processes. Thus, although we recognize that an elastic rheology is clearly an oversimplification for the lithosphere, our results in the companion paper comparing elastic and viscoelastic models demonstrate that the first-order effects of rift pillows can be established using an elastic rheology. This is especially true if, as we presume, the local stresses generated today arise from a structure formed hundreds of millions of years ago. Whatever viscoelastic relaxation took place in the Amazonas rift has long since ended, and we are left with the load primarily supported elastically.

Grid and loading information for the modeling are shown in Figure 2. Grid geometry and density information are based on profiles B-B' and C-C', two different cross sections roughly perpendicular to the rift axis (see Figure 1) [after Nunn and Aires, 1988]. The grid for profile C-C', shown in Figure 2a, crosses the rift at the point where the rift pillow has its maximum width of about $200 \mathrm{~km}$ and occurs near a bend in the rift. The grids for profile B-B', shown in Figures $2 b$ and $2 c$, cross the rift where the rift pillow has a more typical width of 100 $\mathrm{km}$. All grids shown in Figure 2 have a lithospheric thickness of $100 \mathrm{~km}$. A $3000-\mathrm{km}$-wide coarse grid centered on the rift axis with 1859 quadrilateral elements in a state of plane strain was used for profile C- $C^{\prime}$ (Figure 2a). The models for the narrower profile B-B' (Figures $2 \mathrm{~b}$ and $2 \mathrm{c}$ ) utilized a $2650-\mathrm{km}$-wide fine grid with 4860 elements having about twice the spatial resolution of the coarse grid in Figure 2a. Profile B-B' was modeled with both a coarse- and a fine-scale representation of the rift pillow load, as shown in Figures $2 b$ and $2 c$, respectively.

The boundary conditions for all models include horizontal displacement pinned at the center of the base of the model to constrain rigid body translation, stress-free edges of the grid far from the rift axis, and Winkler restoring forces at all density interfaces. The edge boundary conditions are justified by the assumption that, after hundreds of millions of years, the load of the rift pillow is supported by local shear stress and not by the distant edges of the grid. The Winkler restoring forces are proportional to the density contrast across the interface and model an isostatic gravitational restoring force associated with the deflection of density interfaces. The reference lithosphere, taken from the gravity modeling of Nunn and Aires [1988], consists of a $20-\mathrm{km}$-thick surface layer of density $2750 \mathrm{~kg} / \mathrm{m}^{3}$, a $34-\mathrm{km}^{-}$-thick lower crustal layer of density $2850 \mathrm{~kg} / \mathrm{m}^{3}$, and a lithospheric mantle layer of density $3300 \mathrm{~kg} / \mathrm{m}^{3}$. We assume a Poisson's ratio of 0.25 and a constant Young's modulus of 70 GPa for the lithosphere, except for basin sediments, which have a lower Young's modulus of $700 \mathrm{MPa}$.

The loads in the model are included as density contrasts with the surrounding lithosphere, also taken from the gravity modeling of Nunn and Aines [1988]. For model C-C' shown in Figure $2 \mathrm{a}$, these include a positive $150 \mathrm{~kg} / \mathrm{m}^{3}$ contrast between the rift pillow and the surrounding crustal material and a negative $200 \mathrm{~kg} / \mathrm{m}^{3}$ contrast between the low-density basin fill sediments and the crust. For the coarse B-B' profile model shown in Figure 2b, a similar low-density basin fill was used, and positive density contrasts of $250 \mathrm{~kg} / \mathrm{m}^{3}$ and $150 \mathrm{~kg} / \mathrm{m}^{3}$ were used between the rift pillow and upper and lower crustal material, respectively. For the fine B-B' ${ }^{\prime}$ profile model shown in Figure $2 c$, we have specifically included negative density contrasts associated with deflection of midcrustal and Moho boundaries. Since only anomalous mass is considered in our models, the calculated stresses represent those due solely to the anomalous density structures. Furthermore, we assume a lithostatic reference state of stress in the lithosphere [McGar, 1988]. We would have to use artificial horizontal boundary conditions to achieve a lithostatic reference stress state if gravity acted on the entire density structure. Thus the total stress state is the sum of our calculated compressional and tensional stresses due to the anomalous density, any regional stresses, and the reference lithostatic stress. The total stress state is always compressional, even when our predicted stresses are tensional. To emphasize this point, we refer to our calculated tensional stresses as nonlithostatic tension.

\section{Results of Modeling}

The predicted stresses for the central portion of profile C-C' are shown in Figure 3. The complete grid extends horizontally from $-1000 \mathrm{~km}$ to $+2000 \mathrm{~km}$. Loads in the model (areas of nonzero density contrasts) are indicated by shading and have been shown in greater detail in Figure $2 \mathrm{a}$. The general stress pattern computed for this simple model applies to all models: maximum compression directly above the rift pillow, maximum nonlithostatic tension below the load, a neutral plane near the middle of the lithosphere, and stresses of opposite polarity on the flanking flexural bulges. The largest compressional stresses for this model occur near the surface above the rift pillow and have a magnitude of $99 \mathrm{MPa}$. Comparable magnitude nonlithostatic tensional stresses develop below the rift pillow in the lower lithosphere. Stresses decrease rapidly away from the buried rift and are very small beyond the central position of the grid shown in Figure 3. This is consistent with local support for the buried load and the stress-free boundary conditions assumed for the edges of the model.

Results for the more typical rift profile B-B', using the fire resolution grid and coarse loading geometry of Figure $2 b$, are shown in Figure 4. The stress patterns are very similar to those for profile $\mathrm{C}-\mathrm{C}^{\prime}$, except that the maximum compressive stress magnitude above the rift is now $105 \mathrm{MPa}$. The similarity in stress patterns for the two loads indicates an insensitivity to grid resolution and width. In order to test the role of load resolution, however, we present a model in Figure 5 for profile B-B' with the much finer resolution of the anomalous density material shown in Figure $2 \mathrm{c}$. This model includes negative 

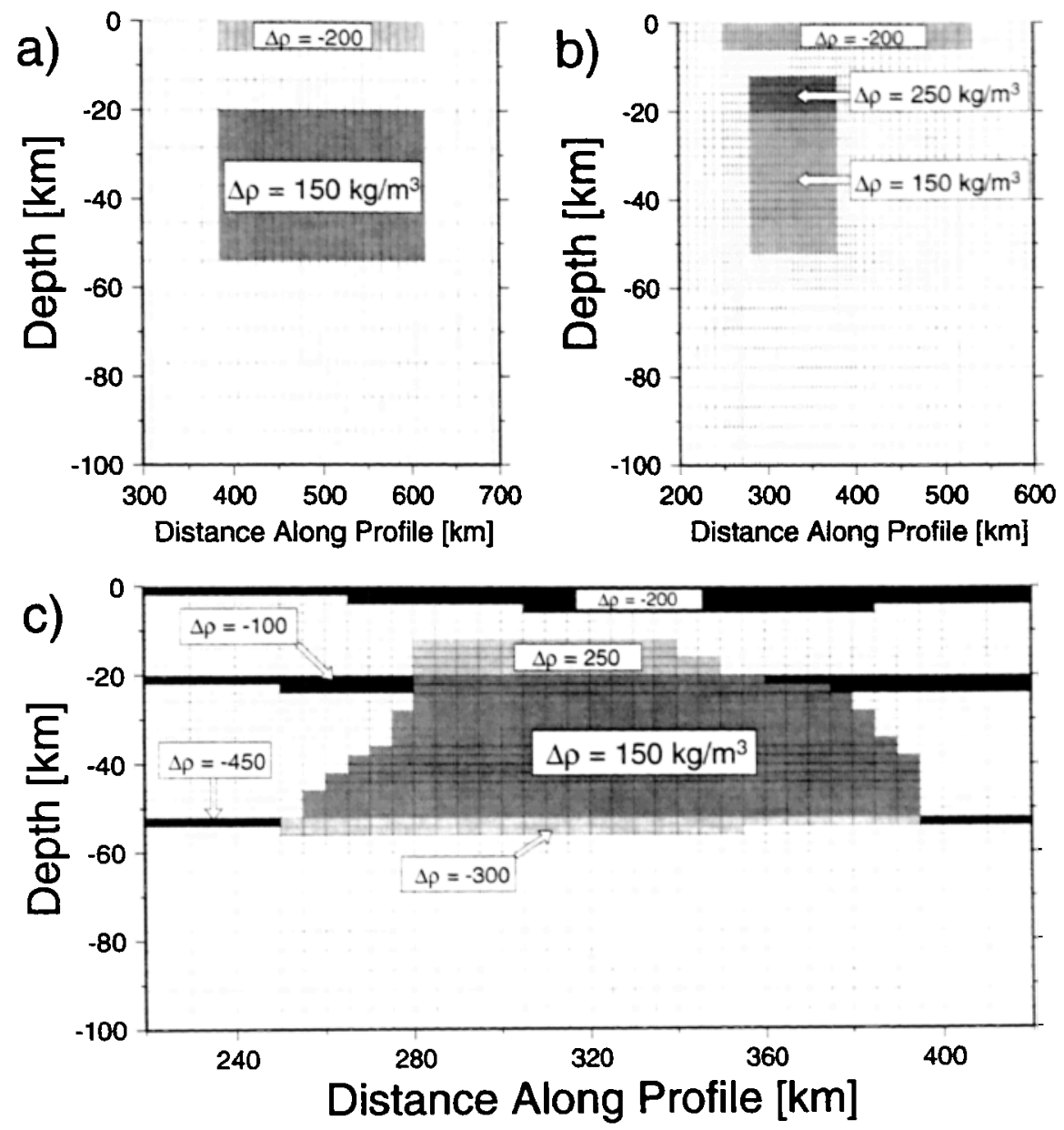

Figure 2. Central portions of the two-dimensional finite element grids used in the study (see Figure 1 for location of profiles). All grids extend vertically over a $100-\mathbf{k m}$-thick lithosphere and consist of elastic quadrilateral elements in a state of plane strain. The boundary conditions include (1) pinning the horizontal displacement at the center of the base of the grid to constrain rigid body translation, stress-free edges and top. and (2) Winkler restoring forces at all density interfaces proportional to the density contrast across the interface. The vertical scale is the same for Figures $2 a-2 c$, while the horizontal scale is twice as large for Figure 2c. (a) Central portion of the 1859 element coarse grid for profile $C-C^{\prime}$, which extends from -100$) 0 \mathrm{~km}$ to $+2000 \mathrm{~km}$ horizontally. A positive density contrast of $150 \mathrm{~kg} / \mathrm{m}^{3}$ is asscciated with the rift pillow. A negative density contrast of $-200 \mathrm{~kg} / \mathrm{m}^{3}$ is associated with low-density basin sediments. (h) Central portion of the 4860-element fine grid with the coarse loading geometry for profile B-B'. The complete grid extends from $-1000 \mathrm{~km}$ to $+2650 \mathrm{~km}$ horizontally. The narrower rift pillow for protile $\mathrm{B}^{-B^{\prime}}$ consists of $250 \mathrm{~kg} / \mathrm{m}^{3}$ and 1511 $\mathrm{kg} / \mathrm{m}^{3}$ density contrasts between the rift pillow and upper and lower erustal reference material, respectively, as well as low-density basin sediments with a density contrast of $-2(k) \mathrm{kg}^{3} \mathrm{~m}^{3}$. (c) Central portion of the 4860 -element tine grid with the fine loading geometry for profile B- $\mathrm{B}^{\prime}$. The complete grid extends from - 1 (100) $\mathrm{km}$ to $+2650 \mathrm{~km}$ horizontally. In addition to the density contrasts in Figure $2 \mathrm{~b}$, there are density contrasts of $-100 \mathrm{~kg} / \mathrm{m}^{3}$ and $-4.50 \mathrm{~kg} / \mathrm{m}^{3}$ associated with deflections of miderustal and Moho interfaces, respectively. There is also a $-300 \mathrm{~kg} / \mathrm{m}^{3}$ density contrast at the base of the structure assexiated with deflection of the rift pillow across the Moho.

density contrasts of $100 \mathrm{~kg} / \mathrm{m}^{3}$ and $450 \mathrm{~kg} / \mathrm{m}^{3}$ associated with deflections of the upper crust across a miderustal boundary and of the lower crust across the Moho, respectively. In addition. there is a negative $300 \mathrm{~kg} / \mathrm{m}^{3}$ load beneath the rift pillow where it is deflected across the Moho. The load is much more realstically included in this model, but the pattern of the predicted stresses is very similar to that of the coarse loading geometry case in Figure 4. The overall stress magnitudes are reduced about $15 \%$ compared to Figure 4, which results primarily from the deflection of lower-density material across density houndaries at miderustal and Moho depths. Thus the pattern of the predicted stresses is rather insensitive to details of the loading structure. This is of benetit, given the rather peor information available ahout the detailed subsurface distribution of anomalous density. A 15\%; uncertainty in model stresses is well within the range of stresses predicted for various models considered here and does not affect any conclusions about the relative contribution of rift-generated stresses to the total stress field.

Several factors affect the magnitude of the compression perpendicular to the rift axis. These include the amount of anomalous nass, the width of the anomalous bxdy, and the thekness 


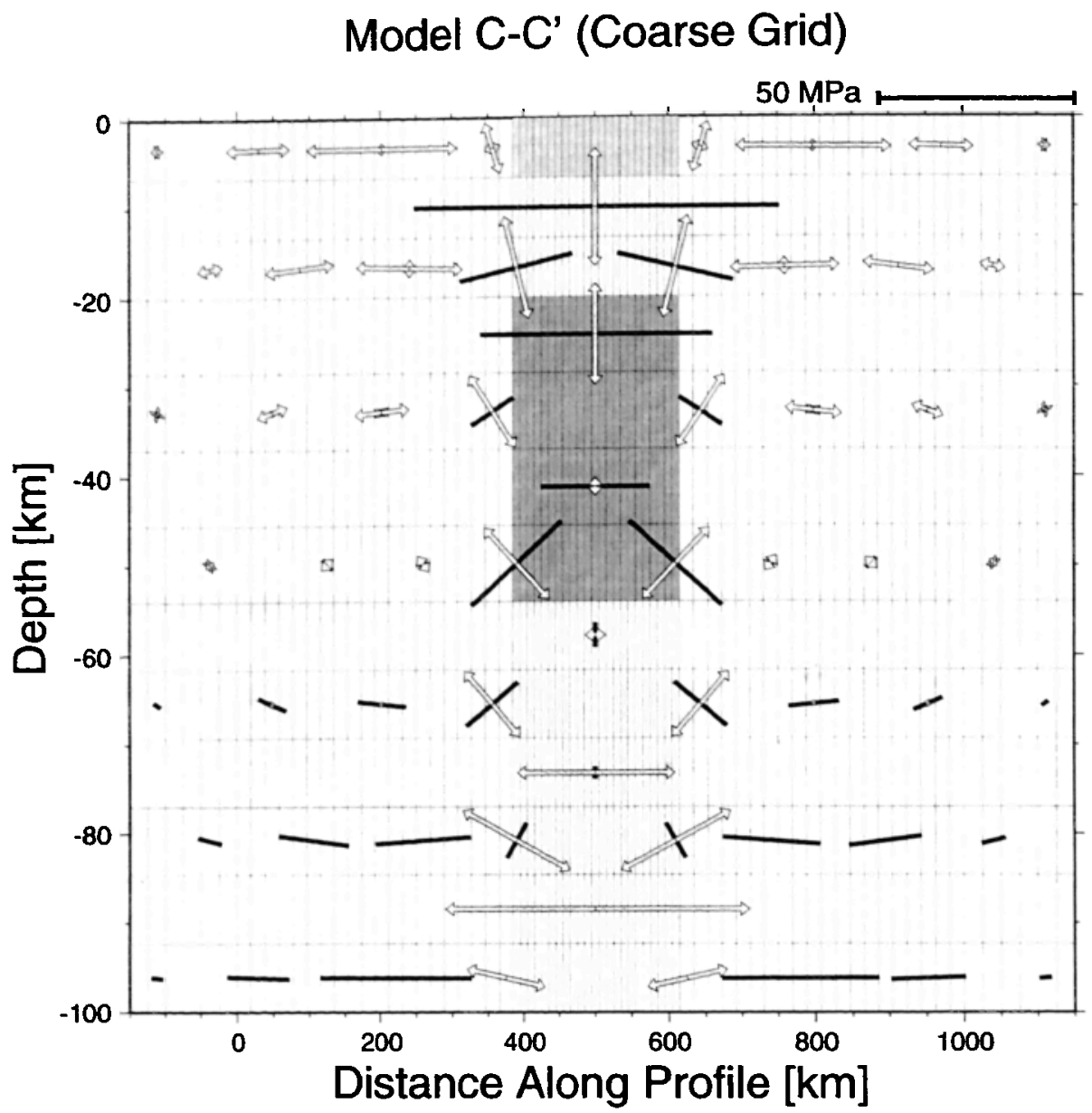

Figure 3. Predicted nonlithostatic stresses using the coarse grid and coarse loading geometry for profile C-C' [after Nunn and Aires, 1988] across the Amazonas rift. The rift pillow is widest along this profile. Horizontal compressive stresses as large as $99 \mathrm{MPa}$ develop above the buried rift. See Figure 2a for other details of the density distribution. See text for other details.

over which the load is supported. There is more anomalous mass for profile $C-C^{\prime}$ than for profile B-B' (Figure 2), but the decrease in width for profile $B-B^{\prime}$ almost exactly compensates for the smaller mass, resulting in very similar predicted stress magnitudes for the two cases. Lithospheric thickness also plays a fundamental role in determining stress magnitudes, with bending stresses increasing with thinner lithosphere and decreasing with thicker lithosphere. A model for profile C-C' with a lithospheric thickness of $150 \mathrm{~km}$ produces stress patterns very similar to those shown in Figure 3, with a reduced maximum compressive stress magnitude of $63 \mathrm{MPa}$. Maximum compressive stress magnitudes increase to $122 \mathrm{MPa}$ if the lithospheric thickness is decreased to $70 \mathrm{~km}$. However, for lithospheric thickness any smaller than about $70 \mathrm{~km}$, the neutral plane moves to such a shallow depth that nonlithostatic horizontal tension is predicted at depths where the thrustfaulting earthquakes have occurred. Our finite element modeling thus indicates that support of the rift pillow generates rift-normal horizontal compressive stresses above the neutral plane with magnitudes in the range of $60-120 \mathrm{MPa}$, with values of $80-100 \mathrm{MPa}$ probably most representative of the overall structure.

\section{Limits of Modeling}

The finite element modeling utilized in this study is based on a purely elastic rheology. As discussed in our companion paper [Grana and Richardson, this issue], while including a viscoelastic rheology is physically more realistic, it does not change the basic results. Namely, in all cases gravitational forces acting on the high-density rift pillow induce stresses perpendicular to the rift with magnitudes in the range of $60-120 \mathrm{MPa}$. With a viscoelastic rheology, stress is transferred from layers having short relaxation times to the elastic portions of the model. To first order, the same results are obtained with the elastic rheology by having elastic layers with high Young's moduli correspond to viscoelastic layers with very long relaxation times, and having elastic layers with low Young's moduli correspond to viscoelastic layers with short relaxation times. The major benefit of the viscoelastic approach is prediction of stresses for times of the order of the relaxation time, but for these ancient rifts the relaxation times are probably fairly short compared to the ages of the structures.

We have also explored the sensitivity of the modeling results to the boundary conditions. The maximum compressive stress 


\section{Model B-B' (Fine Grid / Coarse Load Geometry)}

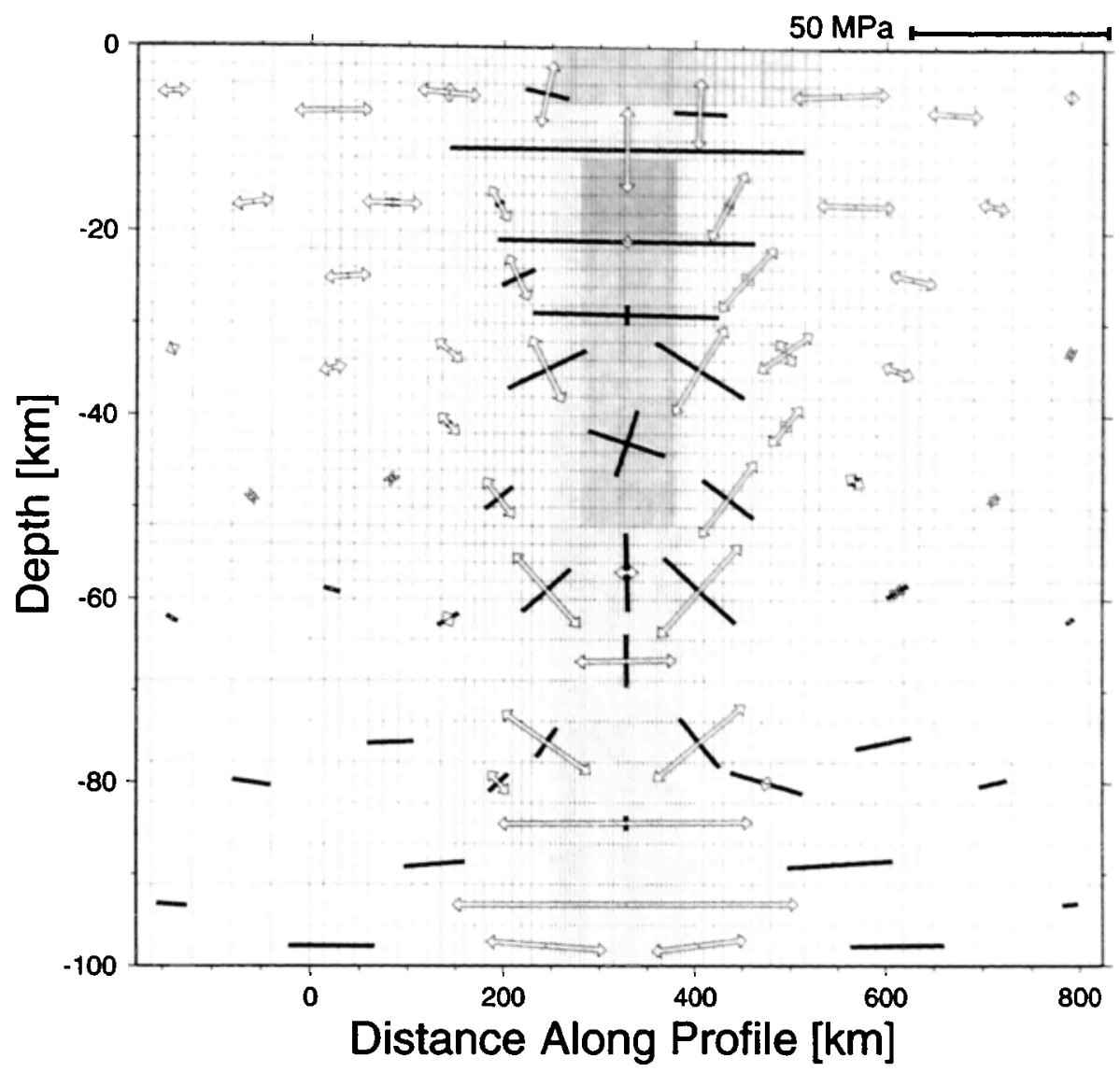

Figure 4. Predicted nonlithostatic stresses using the fine grid and coarse loading geometry for profile B-B' [after Nunn and Aires, 1988] across the Amazonas rift. The rift pillow has a typical width along this profile. See Figure $2 b$ for other details of the density distribution. The stress patterns are very similar to those in Figure 3. The maximum horizontal compressive stress above the rift is $104 \mathrm{MPa}$, comparable to that in Figure 3 . See text for other details.

magnitudes change very little, less than $5 \%$, if the boundary conditions on the lateral edges of the model are changed from stress-free to fixed. This indicates that the load is supported lucally and not by the edges of the model, which are arbitrary. Thus the choice of edge boundary conditions has only minor influences on the magnitude of predicted stresses, and the general pattern near the load is unchanged.

The choice of reference model also plays an important role. As discussed above, we have assumed a lithostatic reference state and have chosen to work exclusively with anomalous densities. This dictates the way in which the Winkler restoring forces are used. If the models use actual densities rather than anomalous densities, then all isostatic support for deflections of the lithosphere occurs at the base of the lithosphere where asthenosphere has been displaced. If only anomalous densities are used, then the Winkler restoring forces must be applied at each density interface in the reference model. The models shown in Figures 3-5 all indicate a vertical component of nonlithostatic tension above the load resulting from the downward deflection of the upper surface. For example, if the upper surface is deflected $300 \mathrm{~m}$, the vertical stress at the surface of the model is zero, but compared to the reference undeformed lithosphere at an equal depth of $300 \mathrm{~m}$, the model is deficient in vertical stress by the equivalent of $300 \mathrm{~m}$ of rock. Thus, as mentioned previously, the model stresses represent departures from the stress state of reference lithosphere. The vertical stress in the lithosphere is never tensiunal. and hence the vertical stresses in Figures 3-5 must be interpreted with caution. Fortunately, we are primarily concerned with the addition of the horizontal local stress due to the rift pillow and the horizontal regional stress, and our modeling indicates that the horizontal components of stress are not very sensitive to the vertical distribution of the Winkler restoring forces.

\section{Stress Rotation Due to Rift-Normal Compression}

The finite element models of the Amazonas rift indicate that compressive stress magnitudes in the upper lithosphere related to support of the rift pillow range from 60 to $120 \mathrm{MPa}$, with values of $80-100 \mathrm{MPa}$ probably most representative of the overall structure. These stress magnitudes are significant compared to estimates of other forces acting on and stressing the lithosphere, such as plate driving forces. The ridge push force is probably the dominant plate driving force acting on the South American plate [Stefanick and Jurdy, 1492; Richardson, 1992]. The magnitude of the ridge push force per unit length of 


\section{Model B-B' (Fine Grid / Fine Load Geometry)}

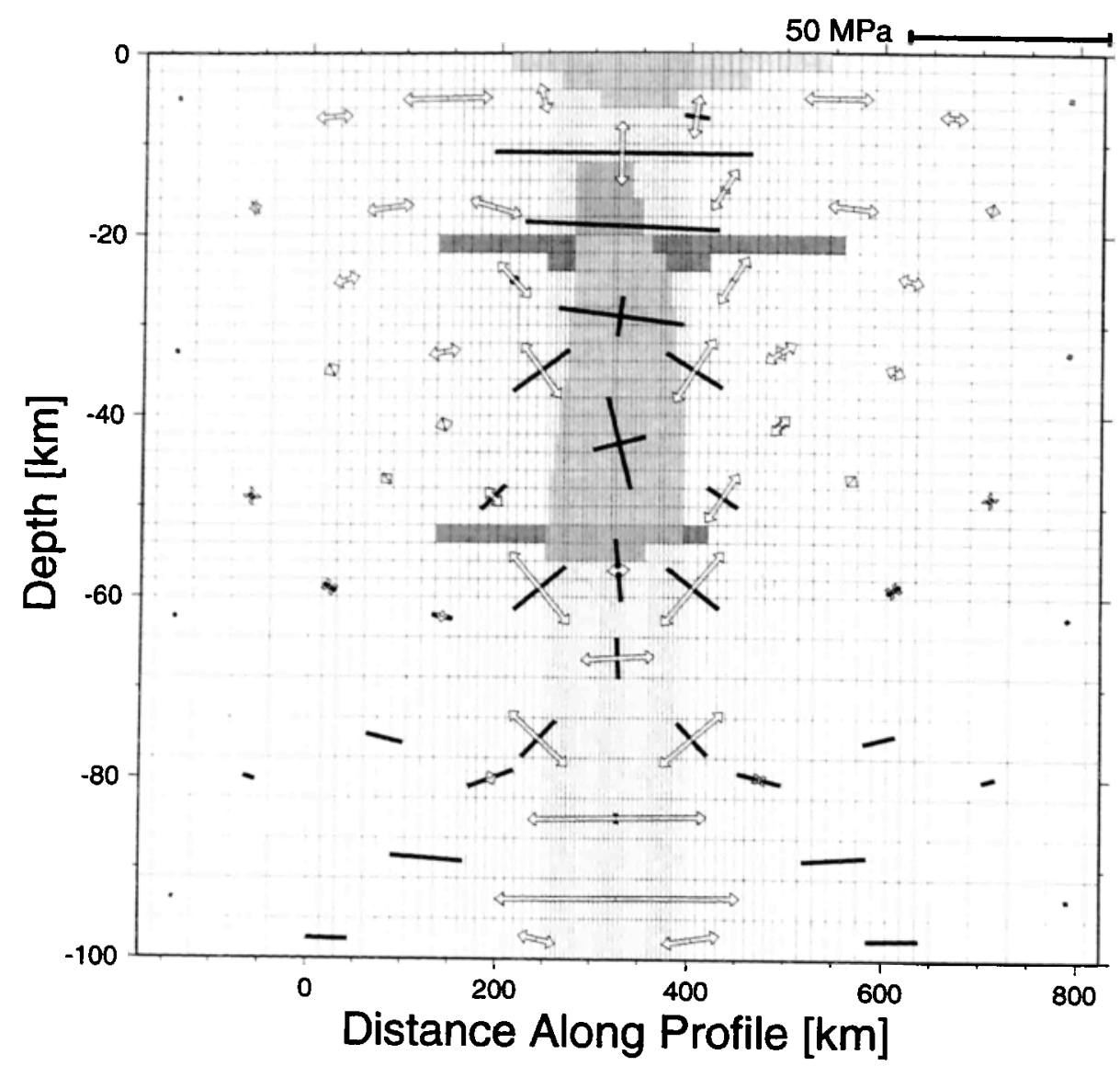

Figure 5. Predicted nonlithostatic stresses using the fine grid and fine loading geometry for profile B-B'. See Figure $2 c$ for other details of the density distribution. The maximum horizontal compressive stress above the rift is $90 \mathrm{MPa}$. The stress patterns are very similar to those in Figures 3 and 4 , with the reduced magnitudes resulting from deflection of low-density material across midcrustal and Moho boundaries. See text for other details.

ridge can be reasonably well determined from the cooling profile of oceanic lithosphere and is estimated at 2 to $3 \times 10^{12}$ $\mathrm{N} \mathrm{m}^{-1}$ [Frank, 1972; Harper, 1975; Parsons and Richter, 1980]. If this load is supported across the entire $100-\mathrm{km}$ thickness assumed for the lithosphere in our models, it is equivalent to an average horizontal stress related to ridge push of only about 20-30 MPa. If the load is supported across a lithosphere with an equivalent elastic thickness of $50 \mathrm{~km}$, the resulting average horizontal stress is $40-60 \mathrm{MPa}$.

The influence of the local rift pillow-induced stress on the regional stress field depends on both the orientation of the rift relative to the regional stress and on the ratio of local to regional stress magnitudes. A simple, but important, observation regarding the significance of this local rift-normal compression is the large apparent rotation of the maximum horizontal stress $\left(S_{H_{\text {max }}}\right)$ in the vicinity of the Amazonas rift relative to the regional E.W direction, as seen in Figure 1. As discussed by Sonder [1990] and Zoback [1992], the amount of rotation $\gamma$ in a horizontal plane of a regional $S_{H_{\text {mat }}}$ direction due to a superposed local deviatoric uniaxial stress $\sigma_{l}$ is given by

$$
\tan 2 \gamma=\frac{\sin 2 \theta}{k-\cos 2 \theta}
$$

where $\gamma$ is the angle between the regional $S_{H_{\max }}$ and the resultant local $S_{H_{\max }}$ (clockwise angles positive), $\theta$ is the strike of the rift relative to the regional $S_{H_{\max }}$ orientation (see inset in Figure 6 for definition of the angles), and $k$ is the stress ratio, determined as follows:

$$
k=\left(S_{H_{\text {mux }}}-S_{h_{\operatorname{man}}}\right) / \sigma_{L}
$$

which is the ratio of the regional horizontal stress difference to the local uniaxial stress. Note that the regional horizontal stress difference is proportional to the maximum regional horizontal shear stress, $\frac{1}{2}\left(S_{H_{\max }}-S_{h_{\operatorname{mon}}}\right)$. The amount of rotation $\gamma$ for various $k$ values for a superposed uniaxial compression is plotted in Figure 6.

In the case of the Amazonas rift, as noted by Zoback [1992]. the overall E-W strike of the Amazonas rift is generally parallel to the mean regional $S_{H_{\max }}$ orientation; thus $\theta \approx 0^{\circ} \pm 10^{\circ}$. As can be seen in Figure 6, for small $\theta\left(|\theta| \leq 10^{\circ}\right)$ large rotations $\left(>75^{\circ}\right)$ occur for $k<1.0$, that is, when the local uniaxial stress dominates the regional horizontal stress difference. The new breakout stress orientation data from the northern margin of the Amazonas rift shown in Figure 1 suggest a mean bal maximum horizontal principal stress orientation of about 


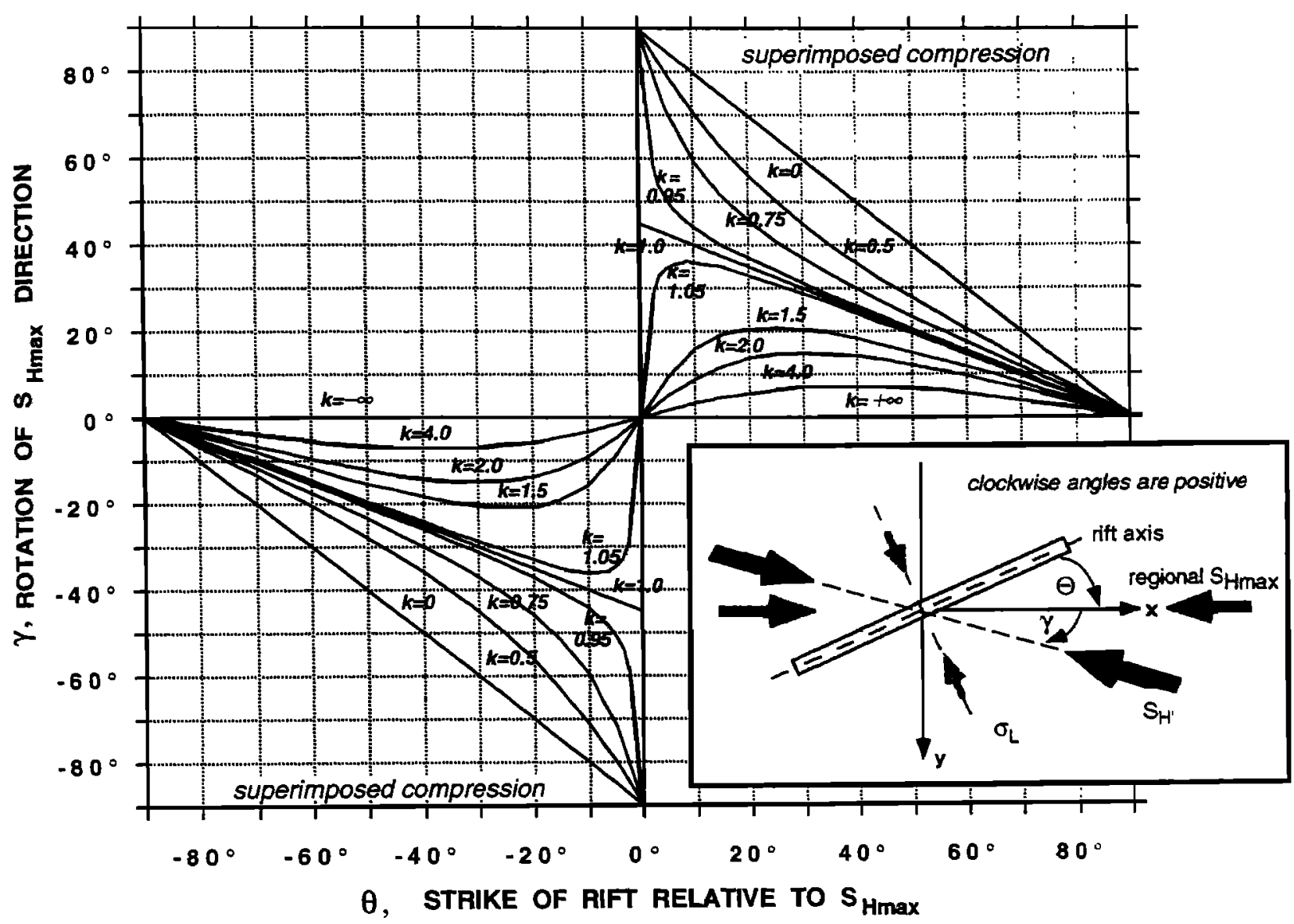

Figure 6. Rotation of regional horizontal stresses as a function of $\theta$, the angle between the strike of the local rift structure that produces the horizontal uniaxial compression, and the regional $S_{H_{\text {max }}}$ direction, computed from (1). Numbers on curves refer to values of the stress ratio $k$, the ratio of the regional horizontal stress differences to the magnitude of the local uniaxial stress $\left(S_{H_{\max }}-S_{h_{\operatorname{mix}}}\right) / \sigma_{L}$ (equation (2)). Inset shows geometry and defines angles.

$\mathrm{N} 15^{\circ} \mathrm{E}$; hence the actual stress rotation (relative to the E-W regional $S_{H_{n}}$ ) may be closer to $\gamma=-75^{\circ}$ rather than $90^{\circ}$. Reference to Figure 6 indicates that for a rotation of $-75^{\circ}$ and small $\theta\left(\theta \leq-10^{\circ}\right.$, note a negative $\theta$ is required to give the proper sense of rotation), the $k$ value is constrained to the range $0.25<k<1.0$. Thus $\sigma_{L}$ must be between 1.0 and 4.0 times larger than the regional stress differences, $S_{H_{\text {max }}}-S_{h_{\text {mun }}}$. As described above, the finite element modeling suggests a mean rift-normal compressive stress value $\left(\sigma_{L}\right)$ of about $80-$ $100 \mathrm{MPa}$ (with a modeled range of $60-120 \mathrm{MPa}$ ). Therefore the predicted regional horizontal stress differences, $S_{H_{\max }}-$ $S_{k_{m m}}$, range from 20 to at most $100 \mathrm{MPa}$ for $0.25<k<1.0$.

\section{Resultant Local Stress Magnitudes}

While the superposition of a local uniaxial stress can rotate the horizontal stresses, the local horizontal stress difference (or equivalently, the horizontal shear stress, since the horizontal shear stress is half the horizontal stress difference) is also modified by the superposition of the local stress. This is true whether or not a stress rotation is observed. Both the magnitude of the resultant local horizontal shear stress and the amount of stress rotation are functions of the stress ratio $k=$ $\left[\left(S_{H_{\text {max }}}-S_{h_{\text {max }}}\right) / \sigma_{L}\right]$ and the orientation of the rift. Using the same geometry defined for computing stress rotation above (see inset in Figure 6), we can show that a normalized, resultant, local horizontal shear stress $R$ is (see the appendix)

$$
\begin{aligned}
R & =\left(S_{H^{\prime}}-S_{h^{\prime}}\right) /\left(S_{H_{\text {max }}}-S_{h_{\text {mat }}}\right) \\
& = \pm \sqrt{1-(2 \cos 2 \theta) / k+1 / k}
\end{aligned}
$$

where $S_{t l}$, and $S_{h}$, are the resultant maximum and minimum horizontal principal stresses, respectively. The choice of the positive or negative root in (3) depends on whether or not the sense of shear on the rift structure changes sign (relative to the regional horizontal stress difference) as a result of the superposition of the local stress. The appropriate roots are determined by the critical rift strike direction, $\theta_{\text {, }}$, which corresponds to a $45^{\circ}$ local stress rotation $\left(|\gamma|=45^{\circ}\right.$ ), which, from (1), occurs when

$$
\cos 2 \theta_{\iota}=k \text {. }
$$

Thus the proper roots for (3) are

$$
\begin{array}{ll}
R=+\sqrt{1-(2 \cos 2 \theta) / k+1 / k^{2}} & k \geq \cos 2 \theta \\
R=-\sqrt{1-(2 \cos 2 \theta) / k+1 / k^{2}} & k \leq \cos 2 \theta .
\end{array}
$$




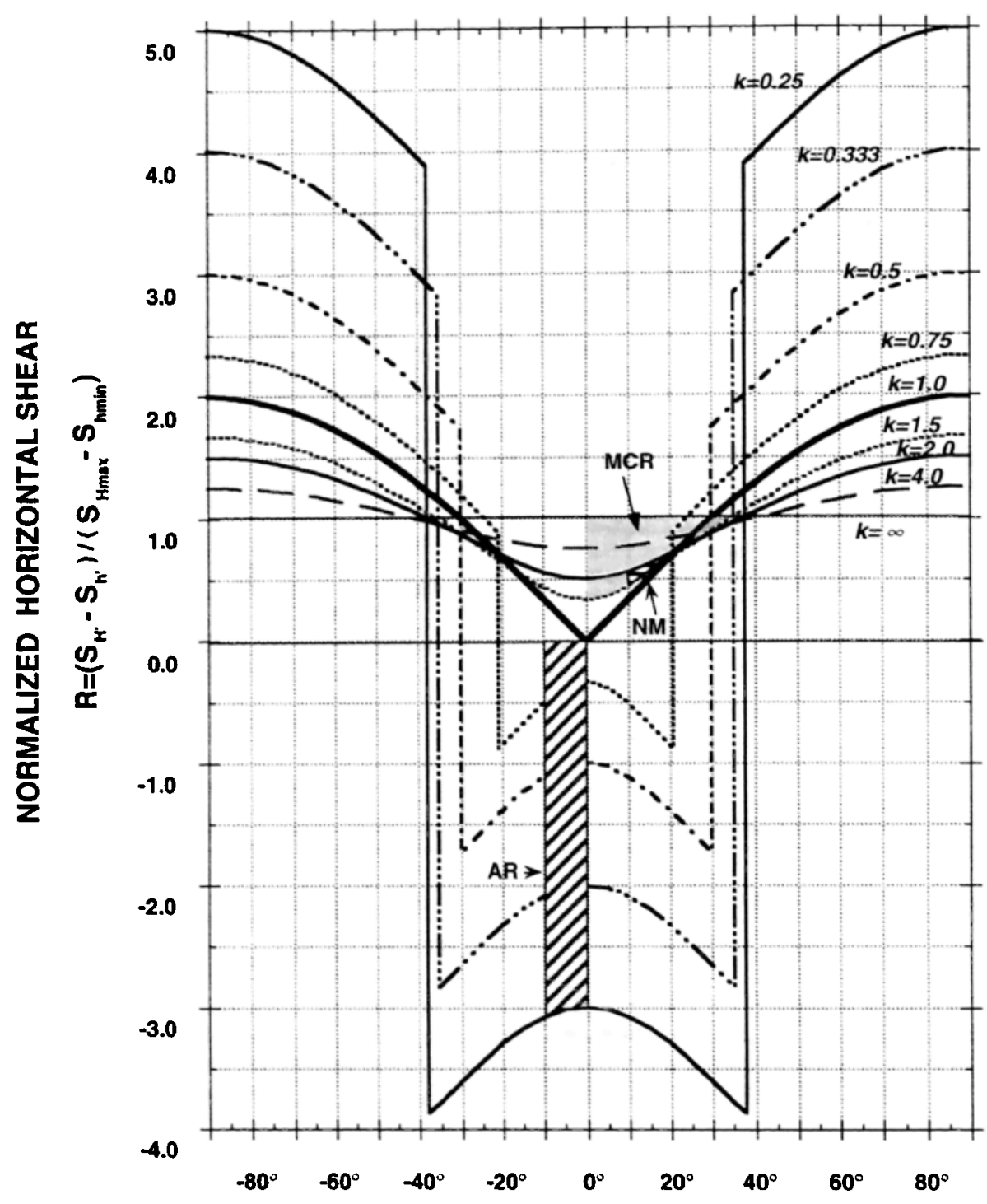

$\Theta$, STRIKE OF RIFT RELATIVE TO $S_{\text {mmax }}$

Figure 7. Plot of $R$, the normalized resultant horizontal shear stress (relative to regional horizontal shear stress) as a function of the relative strike of the rift, $\theta$, for various values of $k$. Shaded regions describe possible stress states discussed in text. AR. Amazonas rift; NM, New Madrid rift: MCR, Midcontinent rift.

The $R$ values derived from (5) are plotted in Figure 7. For $k \geq 1.0$ (when the regional horizontal stress difference is greater than or equal to the local uniaxial stress $\sigma_{L}$ ), $R$ is always positive, achieving a maximum value at $|\theta|=90^{\circ}$, when the local stress adds directly to the regional $S_{h_{\text {mat }}}$, and a minimum value at $H=11^{\circ}$, when $\sigma_{l}$ is superposed on $S_{h}$. As $k$ hecomes large (i.e.. $\sigma$, becomes quite small compared to the regional stress difference), there is less variation in $R$. However, for $k=4$ (regional horizontal stress difference is 4 times $\sigma_{l}$ ), there is still about $20{ }^{\prime}$ ' variation in the $R$ value between the $\theta=0^{\circ}$ and $(x)^{\circ}$ extremes.

In contrast, when the local stress $\sigma_{l}$ exceeds the regional horizontal stress difference $(k<1.0)$, hoth positive and negative values of $R$ are ubtained, with $R$ being multivalued ( \pm ) at the critical strike angle $\theta$, given in (4). Once again, the mini- mum amplification of the resultant horizontal shear stress $\alpha$ curs when $\theta=0^{\circ}$. However, in this case, very large amplifications are possible when $|\theta|=90^{\circ}$.

As described in the previous section, in the vicinity of the Amazonas rift the inferred $\gamma=-75^{\circ}$ rotation of the regional stress field implies $0.25<k<1.0$ (Figure 6). Correspondingly, as shown by the shaded box in Figure 7, the sign of the resultant local horizontal shear stress is opposite that of the regional shear stress $(R<0)$, consistent with the observed large stress rotation. The resultant normalized horizontal shear stress is either reduced or amplified, depending on the actual $k$ value. For $k>0.5$ (local uniaxial compression at least twice the regional stress difference) the resultant shear stress is reduced relative to the regional value $(|R|<1.0)$. However, for $k$ values between 0.5 and 0.25 (local stress 2 to 4 times the 
regional horizontal stress differences, respectively) the local resultant horizontal shear stress is amplified by as much as a factor of 3 for $k=0.25$ (see Figure 7).

Unfortunately, it is not straightforward to predict how the stress rotation and the change in the local horizontal stress difference actually influence the likelihood of frictional failure in a regional thrust-faulting regime, such as applies to the Amazonas rift. The maximum shear stress that drives thrust faulting is the difference between the maximum horizontal and vertical stresses, whereas the stress rotation and $R$ value only provide information on the stress difference in the horizontal plane. As mentioned previously, the model vertical stresses in Figures 3 through 5 are the anomalous stresses compared to a reference undeformed lithosphere. In all the models analyzed, some vertical nonlithostatic tension develops at seismogenic depths. Since the actual vertical compressive stress increases from the deflected free surface and not from the undeformed free surface, the model vertical stresses must be interpreted with caution. However, any modeled nonlithostatic tension has the effect of increasing the shear stress on thrust faults. To accurately predict the resultant stress state at depth, however. we need to know any changes in vertical stress plus independent information on the relative magnitude of the regional stresses magnitudes, $S_{h_{\operatorname{man}}}$ and $S_{H_{\text {mux }}}$, to determine if the resultant local maximum shear stress $\left(S_{H^{\prime}},-S_{z^{\prime}}\right)$ is large enough to generate faulting. Detailed discussion of all possible stress states at depth in the vicinity of the Amazonas rift is beyond the scope of this paper. Some specific examples of ranges of superposed stresses on different stress regimes, including a case similar to the Amazonas rift, are described in the next section.

\section{Potential for Fault Reactivation: End-Member Cases}

In the previous sections we described two coupled effects resulting from superposition on the regional stress field of a local uniaxial compression derived from the rift density structure. The first effect is a rotation of the horizontal stress directions, and the second is a modification of the magnitude of the horizontal shear stress. Both effects influence the potential reactivation of preexisting structures and, as described below, may act in concert to either enhance or inhibit the likelihood of faulting in the vicinity of old rifts. Thus stress rotation could result in old rift fault zones being "favorably" oriented with respect to the new local stress field, but at the same time, it could reduce the local horizontal shear stress relative to the regional horizontal shear stress.

It is instructive to first evaluate two end-member examples of superposed rift-normal compression: (1) in which the ancient continental rift is perpendicular to the regional $S_{H_{\text {ma }}}$ orientation (Figures $8 \mathrm{a}$ and $8 \mathrm{~b}$ ), and (2) in which the ancient rift is parallel to the regional $S_{H_{\operatorname{ma}}}$ orientation (Figures $8 \mathrm{c}$ and \&d, similar to the Amazonas case). Stress magnitude-withdepth plots for both thrust and strike-slip regimes on Figure 8 illustrate, in a general way, the effect of the superposed local rift-normal compression, $\sigma_{t,}$. In all cases the magnitude of the regional intermediate stress $S_{2}$ is assumed to be the arithmetic mean of $S_{1}$ and $S_{3}\left(S_{2}=\left(S_{1}+S_{3}\right) / 2\right)$, a common assumption about the crustal stress state due to lack of information on true stress magnitudes. Three possible values for $\sigma_{l}$ are considered on each plot.

1. A small local uniaxial stress, $\sigma_{L_{211}}$, which corresponds to $k=2.0$ :

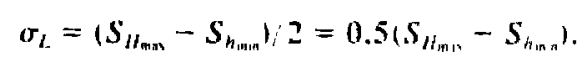

2. The variable $\sigma_{l_{l}, 1}$, corresponding to $k=1.0$ :

$$
\left(S_{I_{\text {max }}}-S_{h_{\text {mot }}}\right)=\sigma_{l} .
$$

3. A large local uniaxial stress. $\sigma_{I_{11} 0^{*}}$ which corresponds to $k=0.5$ :

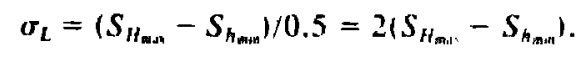

The simplest case occurs when the rift strikes perpendicular to the regional $S_{H_{\text {max }}}$ orientation $\left(\theta= \pm 90^{\circ}\right.$. Figures 8 a and $\left.8 b\right)$. Superposition of $\sigma_{l}$ increases the magnitude of $S_{H_{\text {max }}}$, raising it to $S_{H}=S_{H_{\max }}+\sigma_{L}$ and leaves the magnitude of the minimum horizontal stress unchanged, $S_{h}=S_{h_{\operatorname{man}}}$. As shown on Figure 6, for $\theta= \pm 90^{\circ}$ no stress rotation occurs, regardless of the $k$ value. The resultant change in horizontal stress differences is

$$
S_{H}-S_{h^{\prime}}=\left(S_{H_{\max }}+\sigma_{l}\right)-S_{h_{\min }}
$$

yielding, when normalized by the regional horizontal stress difference (see (5)),

$$
R=1+1 / k \quad \theta= \pm 90^{\circ} .
$$

As shown in Figure 7, this always results in amplifications of horizontal shear stress; for $k<1.0$ this amplification can be quite large. As shown on the stress-depth plots in Figures 8a and $8 \mathrm{~b}$, the increase in $S_{H_{\max }}$ magnitude directly increases the magnitude of $S_{1}$ (maximum compressive principal stress) in both strike-slip and thrust regimes regardless of the $k$ value, resulting in an increase in the maximum crustal shear stress and hence enhancing the likelihood of faulting in either stress regime. Interestingly, at present we are aware of no modern analog for such a geometry of an ancient rift which strikes perpendicular to the regional maximum horizontal compression direction.

When the rift strikes parallel to the regional $S_{H_{\max }}$ orientation $\left(\theta=0^{\circ}\right.$, Figures $8 \mathrm{c}$ and $\left.8 \mathrm{~d}\right)$, it is more difficult to predict the effect of the superposed rift-normal compression on the likelihood of faulting. Unfortunately, this geometry is relatively common (e.g., Amazonas rift. New Madrid (Reelfoot) rift. and Midcontinent rift in the central United States). In this case, superposition of $\sigma_{l}$ increases the magnitude of minimum regional horizontal stress, raising it to $S_{h}=S_{h_{m+4}}+\sigma_{l}$, while leaving the magnitude of the maximum horizontal regional stress unchanged $\left(S_{H I}=S_{H_{\max }}\right.$ ) (Figures $8 \mathrm{c}$ and $8 \mathrm{~d}$ ). The resultant horizontal stress difference is

$$
S_{H},-S_{h}=S_{H_{\text {max }}}-\left(S_{h_{\min }}+\sigma_{l}\right)
$$

and the normalized horizontal shear stress is (from (5))

$$
R=1-1 / k \quad \theta=0^{\circ} .
$$

Thus for $\theta=0^{\circ}$, the resultant horizontal shear stress is reduced whenever the regional stress difference dominates the local uniaxial stress $(k>1.0)$, and no stress rotation occurs (c.g. $\sigma_{I_{211}}$ and $\sigma_{L_{111}}$ on the stress-depth plots in Figures $8 \mathrm{c}$ and $8 \mathrm{~d}$ ). However, when the local uniaxial stress dominates $(k<1.0)$. the horizontal stress axes rotate $90^{\circ}$ (horizontal stress axes exchange, e.g., $\sigma_{L_{1,1}}$ in Figures $8 c$ and $\left.8 d\right)$. In this case the resultant shear stress can be reduced $(1.0<k<0.5)$ or amplified ( $0<k<0.5$ ) (see Figure 7). When the local uniaxial stress is exactly equal to the regional horizontal stress 

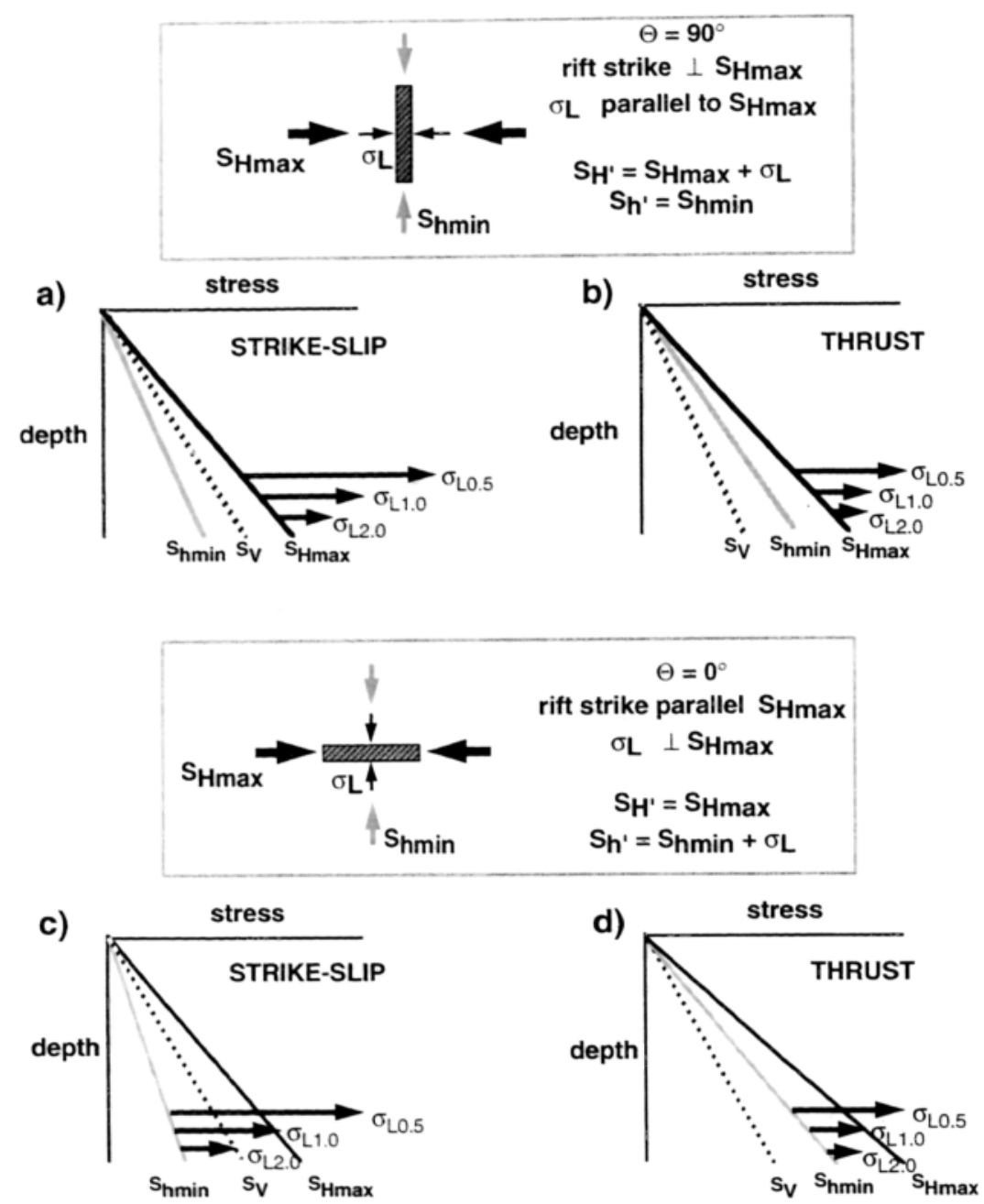

Figure 8. Stress magnitude as a function of depth plots for two end-member cases of rift orientation using examples of three values of superposed rift-normal compression. (1) A small, local uniaxial stress, $\sigma_{L}$, corresponding to a $k=2.0$; a moderate, local uniaxial stress, (2) $\sigma_{L_{1} \ldots}$. corresponding to $k=1.0$; and (3) a large local uniaxial stress, $\sigma_{L_{11} 5^{\circ}}$ corresponding to $k=0.5$ (see text). (a) Variable $\theta=90^{\circ}$, rift perpendicular to $S_{H_{\text {ma }}}$, strike-slip stress regime; (b) $\theta=90^{\circ}$, rift perpendicular to $S_{H_{\text {max }}}$, thrust stress regime; (c) $\theta=0^{\circ}$, rift parallel to $S_{/ H_{\max }}$, strike-slip stress regime; (d) $\theta=0^{\circ}$, rift parallel to $S_{H_{\max }}$, thrust stress regime.

difference ( $k=1.0:$ see $\sigma_{L_{1} \text {, }}$ on Figures $8 \mathrm{c}$ and $\left.8 \mathrm{~d}\right)$ for $\theta=$ $0^{\circ}$, a stress "cancellation" occurs, the two horizontal stresses become equal, and hence the rotation is undefined and, correspondingly, the normalized resultant local horizontal shear $R$ must equal 0 , as can be determined by substituting into (9) above.

The results of this two-dimensional analysis for the $\theta=0^{\circ}$ case can be used to evaluate potential reactivation of the rift in a regional strike-slip regime. A relatively small increase in the magnitude of $S_{h_{\text {mut }}}$ due to superposition of $\sigma_{l}$ decreases the maximum shear stress and hence would tend to inhibit faulting (e.g., $\sigma_{1, \ldots}$ case in Figure $8 \mathrm{c}$ ), whereas if the local stress is relatively large ( $\sigma_{L_{1},}$, case in Figure $8 \mathrm{c}$ ), both of the resultant horizontal stresses exceed the vertical stress and the stress regime switches to one of thrust faulting.

For a regional thrust-faulting regime it is much more difficult to assess the likelihood of fault reactivation because prediction of the actual change in the maximum crustal shear stress $\left(S_{1}-\right.$ $S_{3}$ ) critically depends on knowledge of both changes in the vertical stress and on the relative magnitude of the regional
$S_{h_{\text {man }}}$. As noted previously, on all the stress-depth plots in Figure 8 the value of the intermediate stress is shown as exactly halfway between the maximum and minimum stress $\left(S_{h_{\min }}=\right.$ $\left.\frac{1}{2}\left(S_{H_{\operatorname{mat}}}-S_{l} \cdot\right)\right)$ for lack of any additional information. Clearly. if the true value of the intermediate stress is actually closer to either the maximum or minimum stress, then the effect of the superposed stress in the $S_{h_{\text {min }}}$ direction may be quite different than described below.

However, it is still useful to examine the effects of various local superposed stresses on a regional thrust regime for the $\theta=0^{\circ}$ case shown in Figure 8d. For a small, local uniaxial stress $\left(\sigma_{L_{21}}\right.$ or $\sigma_{L_{111}}$ in Figure 8d) the resultant horizontal shear stress is reduced, and the maximum crustal shear stress in the thrust regime $\left(S_{H}-S_{l}\right)$ remains unchanged; hence the likelihood of reactivation on well-oriented structures does not change.

In contrast, when the local stress exceeds the regional horizontal stress difference $(k<1.0$, similar to the Amazonas case), a $90^{\circ}$ horizontal stress rotation is predicted (Figure 6), and as noted previously, the horizontal shear stress may be 


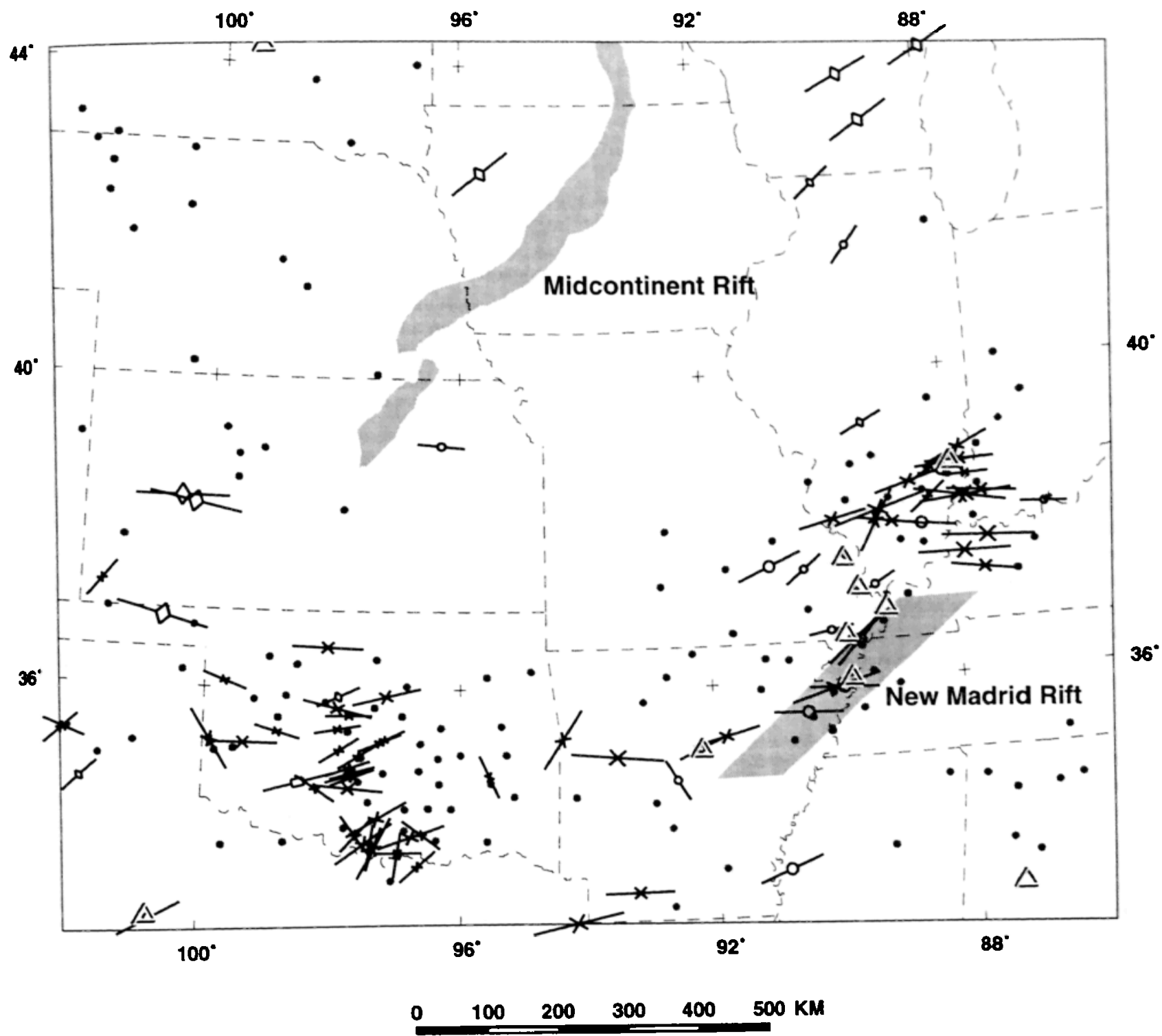

Figure 9. Seismicity and maximum horizontal stress directions in the central United States. The Midcontinent rift (as defined by the $+15 \mathrm{mGal}$ isostatic residual gravity contour from the isostatic residual gravity map of the United States [Simpson et al., 1986]) and New Madrid rift boundaries [Hildenbrand. 1985] shown by shading. Earthquake epicenters from U.S. Geological Survey National Earthquake Information Center diatabase: $3.0<M<4.5$ epicenters are shown by circles; $4.5<M<6.0$ epicenters are indicated by open triangles. Line lengths of stress data are proportional to quality (A-C data plotted; see Zoback [1992] for description of quality ranking); center symbol indicates data type (see Figure 1).

amplified $(0<k<0.5)$ or reduced $(0.5<k<1.0)$. Recall for the Amazonas case that the rotation only constrained $k$ to be between 0.25 and 1.0 ; thus while the large rotation resulted in a favorable stress orientation for reactivating old rift-normal faults as thrusts, we are unable to conclude whether the resultant maximum crustal shear stress that drives thrust faulting $\left(S_{i}^{\prime}-S_{i}^{\prime}\right)$ is locally amplified or reduced.

\section{Application to Other Continental Rifts}

In global analyses of seismicity in stable continental interiors, Basham [1989], Johnston [1989], Johnston and Kantor [1990], and Mitchell et al. [1991] noted a correlation between the occurrence of intraplate earthquakes and ancient continen- tal rift zones. If a dense, lower crustal rift pillow is a significant feature of many such rifts, then the Amazonas example and end-member cases described above offer evidence that some rift pillows may locally modify the intraplate stress and enhance the likelihwod of reactivation of preexisting fault zones. thus providing a physical explanation for the observed correlation. Does the present-day stress field in the vicinity of other ancient continental rifts show any indication of the effects of a superposed local rift-normal compression?

As described in the companion paper by Gruno and Richardson [this issue], seismic refraction studies in the New Madrid region have identified a rift pillow beneath the NE trending Reelfoot rift (Figure 9). In this case the rift strikes subparallel 
to the regional $S_{H}\left(\theta \leq+15^{\circ}\right.$ to $\left.+20^{\circ}\right)$, and stress data suggest a possible $10^{\circ}$ to $20^{\circ}$ clockwise rotation $\left(\gamma=+10^{\circ}\right.$ to $+20^{\circ}$ ) of the maximum horizontal stress (local mean of $N 75^{\circ}$ to $80^{\circ} \mathrm{E}$ relative to $\mathrm{N} 60^{\circ}$ to $65^{\circ} \mathrm{E}$ mean for the rest of midplate North America [Zoback and Zoback, 1989]). As can be seen on Figure 6 , this rotation implies a $k$ value of 1.5 to 2.0 (riftnormal compression of one-half to two-thirds of the regional horizontal stress differences) and results in a $20-40 \%$ local reduction in horizontal shear stress relative to regional horizontal shear stress (see Figure 7). Thus while the stress perturbation results in a local stress orientation more favorable for reactivation of the main strike-slip zone along the axis of the rift, the local horizontal shear stress is reduced, requiring a reduced strength in the fault zone relative to the surrounding crust. An implied reduced strength associated with the active seismic zone could possibly be related to elevated pore pressure, as has been suggested by others on the basis of a lowvelocity zone spatially correlated with the seismicity inferred from inversion of local earthquakes [Al-Shukri and Mitchell, 1987a, b] and from detailed seismic refraction studies of the active seismic zone [Mooney et al., 1983].

It is interesting to contrast the high level of seismicity in the vicinity of the New Madrid rift with the general lack of seismicity associated with the Midcontinent rift system, a similarly oriented ancient rift structure located $700 \mathrm{~km}$ to the NW of the New Madrid rift (Figure 9). The southern arm of the Midcontinent rift extends in a NE direction from eastern Kansas to the Great Lakes region and is marked by the largest positive isostatic residual gravity anomaly in the United States [Simpson et al., 1986]. The source of the observed gravity high along the axis of the rift is probably both a densified upper crust (mafic flows and sills) and lower crust (sills and/or underplating) [King and Zietz, 1971; Behrendt et al., 1988]. The large volume of excess mass implied by the isostatic residual gravity anomaly might be expected to cause a rather large rift-normal compression.

Very little stress information exists in the vicinity of the Midcontinent rift. As shown in Figure 9, only two reliable stress orientation data are available within $100 \mathrm{~km}$ of the rift: (1) a series of nine stress measurements made in granite between 500 and $600 \mathrm{~m}$ depth near Quimby, Iowa, indicating a strike-slip stress regime and a mean $S_{H_{\max }}$ orientation of $\mathrm{N} 52^{\circ} \mathrm{E}$ $\pm 5^{\circ}$ [Haimson and Lee, 1992], and (2) an $\sim \mathrm{E}-\mathrm{W} S_{H_{\max }}$ orientation inferred from a thrust-faulting microearthquake focal mechanism in northeastern Kansas in which the nodal planes were constrained to within $\pm 10^{\circ}$ (D. W. Steeples, written communication, 1979, in the work by Zoback and Zoback [1980]). Both data points are generally consistent with a $\mathrm{N} 65^{\circ} \mathrm{E} \pm 20^{\circ}$ midplate regional $S_{H_{\text {mux }}}$ orientation and suggest no discernible stress rotation $\left(\gamma \leq 20^{\circ}\right)$.

The strike of the Midcontinent rift in this region (using the axis of the gravity high shown in Figure 9 to approximate the shape of the lower crustal dense body) is about $N 40^{\circ}-50^{\circ} \mathrm{E}$, implying a strike relative to the regional $S_{H_{m a x}}$ orientation of $\theta=20^{\circ} \pm 20^{\circ}$. Reference to Figure 6 indicates that for this small $\theta\left(20^{\circ} \pm 20^{\circ}\right)$, no observable rotation $\left(\gamma<20^{\circ}\right)$ occurs when $k \geq-1.5$ (see shaded area on Figure 7). In this case the local horizontal stress difference (shear stress) in the vicinity of the rift may be reduced by up to $60 \%$ relative to the regional shear stress, a value very similar to that inferred for the New Madrid rift as described above. Thus the present-day stress state in the vicinity of these two subparallel ancient rifts is rather similar, suggesting that stress perturbation due to a lower crustal rift pillow is probably not the cause of the mark- edly different levels of seismicity associated with them. The pattern of intraplate seismicity shown on Figure 9 suggests that the different levels of seismic activity between the New Madrid (Reelfoot) and the Midcontinent ancient rift zones may be better explained by a contrast in strength of the lithosphere between the old (cold?) stable interior platform region of the United States and the surrounding younger intraplate regions that possibly have higher heat flow. Zoback et al. [1993] have suggested that in shield and platform regions characterized by low heat flow $\left(-40 \mathrm{~mW} / \mathrm{m}^{2}\right)$ the lower crust and upper mantle are relatively cold and appear to be so strong that the cumulative strength of the lithosphere exceeds the force available to deform it from such sources as ridge push. In contrast, high shear-strain accumulation rates measured geodetically $(0.108$ $\mathrm{ppm} / \mathrm{yr}$ ) in the New Madrid region suggest that the lithosphere is rapidly deforming in this region [Liu et al., 1992].

\section{Comparison With Stress Magnitudes Inferred From Crustal Frictional Strength Constraints}

The regional stress differences computed from the observed rotation and the modeling of the local stress can be compared with crustal stress differences determined from the commonly assumed model in which the maximum stress differences in the upper brittle crust are assumed to be limited by the frictional strength of the crust, the so-called "strength envelope" argument:

$$
\frac{S_{1}-P}{S_{3}-P}=\left(\sqrt{1+\mu^{2}}+\mu\right)^{2}
$$

where $S_{1}$ and $S_{3}$ are the maximum and minimum principal stresses, respectively, $P$ is pore pressure, and $\mu$ is the frictional coefficient of the optimally oriented faults [e.g., Sibson, 1974; Brace and Kohlstedt, 1980; Zoback and Healy, 1984, 1992]. This frictional coefficient is generally taken as $\mu=0.60-0.85$ based on laboratory and in situ stress studies, the so-called Byerlee's law [Byerlee, 1978; Zoback and Healy, 1984, 1992]. For a regional thrust-faulting stress regime, $S_{1}=S_{H_{\max }}$ and $S_{3}=S_{v}$ (considered the most appropriate for the Amazonas region on the basis of the regional earthquake focal mechanisms). Equation (10) yields $\left(S_{1}-S_{3}\right)$, or equivalently, $\left(S_{H_{\max }}-S_{V}\right)$ values of about $800 \mathrm{MPa}$ for $20 \mathrm{~km}$ depth for $\mu=0.65$ and hydrostatic pore pressure $\left(P=0.3737 S_{\nu}\right)$. If we assume that $S_{V}$ is equal to the lithostat and that the magnitude of $S_{2}$ (= $S_{h_{\text {mm }}}$ ) is midway between $S_{1}$ and $S_{3}$ (for lack or any additional information on the magnitude of $S_{2}$ ), then (10) implies a regional horizontal stress difference $\left(S_{H_{\max }}-S_{h_{\min }}\right)$ of $\sim 400$ MPa at $20 \mathrm{~km}$ depth. As described at the end of the stress rotation section, the observed $\sim 75^{\circ}$ stress rotation indicates $k$ values between 0.25 and $<1.0$. If we use the mean modeled rift-normal compressional stress of 80-100 MPa, then these $k$ values imply a regional horizontal stress difference $\left(S_{H_{\text {me }}}-\right.$ $S_{h_{\text {min }}}$ ) of between 20 and $100 \mathrm{MPa}$ at the most. Therefore the stress difference predicted by the frictional faulting strength envelope is 4 to 20 times higher than that implied by the observed rotation and the modeled magnitude of the rift stress.

This discrepancy between the strength envelope prediction and that inferred from the stress rotation does not necessarily imply that the frictional strength model for lithospheric stress differences is wrong or inappropriate. As mentioned previously, we have no independent information on the relative magnitude of the regional intermediate stress, $S_{2}=S_{h_{m}}$ Regionally, in the interior of South America, $S_{2}$ may not be 
exactly halfway between $S_{1}$ and $S_{3}$. If $S_{2}$ is actually closer in magnitude to $S_{H_{\text {max }}}$ then $\left(S_{H_{\text {max }}}-S_{h_{\text {mnn }}}\right)<400 \mathrm{MPa}$. Alternatively, the pore pressure may be elevated at depth, effectively reducing the normal stress magnitudes. To explain the very small $\left(S_{H_{\max }}-S_{h_{\min }}=20-100 \mathrm{MPa}\right.$ ) values inferred from the modeling and stress rotation and for $S_{2}=\frac{1}{2}\left(S_{1}+S_{3}\right)$, the pore pressure values at $20 \mathrm{~km}$ depth must be between $0.96 S_{l}$. and $0.84 S_{l^{\prime}}$, respectively, or very close to lithostatic. While the elevated pore pressure explanation may be appealing to explain the occurrence of the deep earthquakes, the consistent $S_{H_{\operatorname{ma}}}$ orientations obtained from shallow well bore breakouts (average depth about $2.5 \mathrm{~km}$ ) imply that the local stress is always greater than the regional horizontal stress difference.

\section{Conclusions}

Analysis of the regional tectonic stress field within the South American plate indicates a general pattem of E-W maximum horizontal compressive stress probably derived largely from compressional plate driving forces, including ridge push and convergent margin forces acting along the plate's primarily N-S western boundary. Within the Brazilian craton, in the vicinity of the E-W trending failed Paleozoic Amazonas rift, both shallow breakout data $(2.0-2.6 \mathrm{~km}$ depth) and crustal earthquake focal mechanisms (20-45 km depth) suggest a nearly $90^{\circ}$ rotation of the maximum horizontal compressive stress to a $\mathrm{N}$ to NNE direction. The source of this local stress rotation is attributed to the addition of a local rift-normal compressive stress related to support of a dense lower crustal "rift pillow," most probably a zone of mafic intrusions formed during the rifting. The geometry and density contrast associated with the Amazonas rift pillow were determined from gravity modeling constrained by seismic reflection data on the rift basin geometry in the upper crust [Nunn and Aires, 1988].

The local stress caused by body forces associated with the high-density rift pillow was determined using two-dimensional finite element modeling assuming a purely elastic rheology. The principal objective of this paper was to demonstrate that stresses associated with ancient rift pillows are potentially as large as or larger than regional stresses due to plate tectonic processes and to describe the effect of the superposition of the local rift-pillow stress on the regional stress field. Thus, although we recognize that an elastic rheology is clearly an oversimplification for the lithosphere, a much more rigorous viscoelastic modeling of the crustal structure associated with the New Madrid rift zone in the companion paper by Grana and Richardson [this issue] demonstrates that the first-order stress effects of rift pillows can be established using an elastic rheology.

Results of the finite element modeling of the Amazonas rift indicate that elastic support of the dense lower crustal rift pillow can generate rift-normal compressional stresses in the upper crust between 60 and $120 \mathrm{MPa}$, with values of 80-100 $\mathrm{MPa}$ probably most representative of the overall structure. Using a previously derived expression for the amount of rotation as a function of strike of the rift relative to the regional stress field, we interpret the observed $\sim 90^{\circ}$ stress rotation as indicating that the ratio of the regional horizontal stress difference to the local rift-normal stress $k$ must be between 0.25 and $<1.0$, implying regional horizontal stress differences between 20 and $<100 \mathrm{MPa}$. These values are significantly less than the predicted maximum stress difference $\left(S_{H_{\text {mat }}}-S_{V^{\prime}}\right)$ of about $800 \mathrm{MPa}$ for midcrustal depths in a thrust-faulting stress rcgime determined from lithospheric strength envelopes based on the frictional strength of the most well-oriented faults. This difference may be explained by a relatively small difference in horizontal stress magnitudes at depth possibly related to elevated pore pressure effects.

In order to evaluate whether or not the superposed rift stress may be a major contributing factor to the association of intraplate seismicity with a number of old zones of continental extension, we derived a general expression for the modification of the local horizontal shear stress due to superposition of the local stress. Whether or not the superposed horizontal riftnormal compression tends to increase the likelihood of frictional failure (increase the maximum crustal shear stress) in an intraplate setting depends on the orientation of the rift relative to the regional $S_{H_{\text {max }}}$ direction, the ratio of rift-normal stress relative to the regional horizontal stress difference, and the stress regime. Both a stress rotation and a modification of the horizontal shear stress potentially influence the reactivation of preexisting structures. These effects may act in concert to either enhance or inhibit the likelihood of faulting in the vicinity of old rifts, or alternatively, they may compete with one another and make it difficult to predict the potential effects on fault reactivation.

The finite element modeling of the stresses associated with the Amazonas rift crustal structure demonstrates that riftnormal compressive stresses can be a significant source of stress compared to other broad-scale sources of stress acting on the lithosphere (such as the those derived from the plate driving forces). The role of such rift-normal stresses on local seismicity and stress can vary considerably between ancient rifts, depending on a number of factors. These factors include the geometry of the rift compared to the regional $S_{H}$ direction, the magnitude of the rift-normal compression, and whether the local stress regime is strike-slip or thrust. In the Amazonas rift case, the $-75^{\circ}$ rotation of the stress field only loosely constrains the ratio of the local rift-normal stress relative to regional horizontal stress difference because of the geometry of the rift axis and the $S_{H_{-a}}$ direction. The resultant horizontal shear stress could be either amplified or reduced relative to the regional horizontal shear stress. Furthermore, because the stress regime both locally and regionally appears to be one of thrust faulting, it is dificult to predict how any change in horizontal shear stress may impact the likelihood of thrust fault reactivation (which depends on the difference between the maximum horizontal stress and the vertical stress).

The modeled rift-normal compressive stress associated with the seismically active New Madrid ancient rift [Grana and Richardson, this issue] appears sufficient to rotate the horizontal stress field $\sim 15^{\circ}-20^{\circ}$ clockwise to an orientation very favorable for reactivation of steep strike-slip faults parallel to the axis of the rift. However, a $20-40 \%$ reduction in the local horizontal shear stress would accompany such a rotation. Stress data in the vicinity of the seismically quiescent Midoontinent rift of the central United States are sparse but suggest a stress state similar to that in the vicinity of the New Madrid seismic zone, suggesting that stress perturbation associated with the dense lower crustal rift pillow is probably not the cause of the markedly different levels of seismic activity associated with the two ancient rifts. The significantly higher seismicity and relatively rapid strain accumulation rates [Liu et al., 1992] in the New Madrid seismic zone indicate that the lithosphere is more easily deformed in that region relative to the Midcontinent rift. 


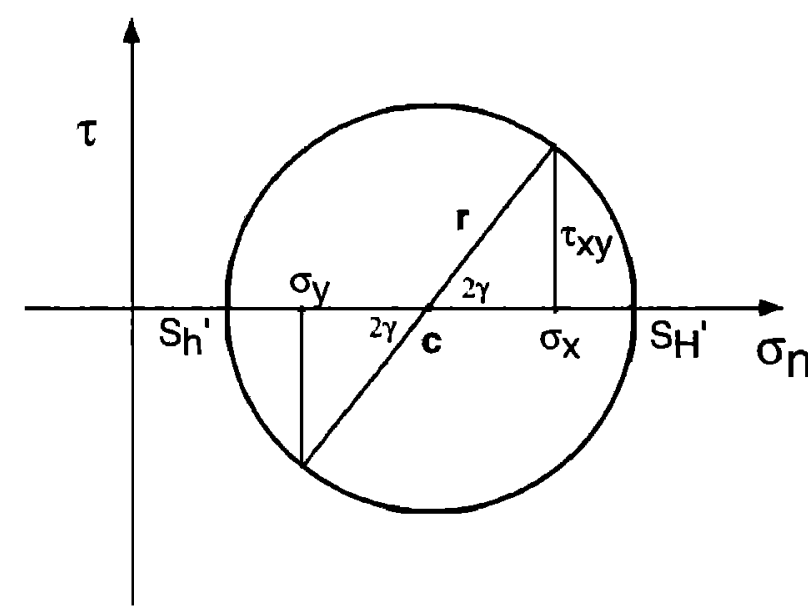

Figure A1. Mohr's diagram for resultant stress state (superposition of regional stress and local uniaxial stress); $\tau$ is shear stress and $\sigma_{n}$ is normal stress.

\section{Appendix: Normalized Resultant Horizontal Stress Differences}

Following Zoback [1992] and using the geometry shown in the inset in Figure 6, we can express the magnitude of the resultant horizontal stresses due to a superposed uniaxial compression $\sigma_{L}$ in a reference principal stress coordinate system (regional $S_{H_{\text {max }}}=x$ axis, after Figure 6):

$$
\begin{gathered}
\tau_{\mathrm{w}}=\frac{1}{2} \sigma_{L} \sin 2 \theta \\
\sigma_{x}=S_{H_{\max }}+\frac{1}{2} \sigma_{L}(1-\cos 2 \theta) \\
\sigma_{v}=S_{h_{\text {min }}}+\frac{1}{2} \sigma_{L}(1+\cos 2 \theta)
\end{gathered}
$$

where $\theta$ is the angle between the strike of the rift structure and the regional $S_{H_{\text {man }}}$ direction.

The resultant local horizontal principal stresses, $S_{H}$, and $S_{h}$, can be determined directly from the two-dimensional Mohr's circle (Figure A1) representing the horizontal stress state given in (A1)-(A3). The center of the Mohr's circle is given by c:

$$
c=\frac{1}{2}\left(S_{H}+S_{h^{\prime}}\right)=\frac{1}{2}\left(\sigma_{\imath}+\sigma_{\imath}\right)
$$

and the radius $r$ is equal to half the resultant horizontal stress differences

$$
r=\frac{1}{2}\left(S_{H}-S_{h}\right)
$$

From Figure A1 the radius of the Mohr's circle is also given by

$$
r^{2}=\left(\sigma_{\lambda}-c\right)^{2}+\tau_{n}^{2} .
$$

Substituting (A1) $(\mathrm{A} 3)$ into (A6) gives

$$
\begin{gathered}
r^{2}=\left\{\frac{1}{2}\left[\left(S_{H_{\max }}-S_{h_{\operatorname{man}}}\right)-\sigma_{L} \cos 2 \theta\right]\right\}^{2}+\left[\frac{1}{2}\left(\sigma_{L} \sin 2 \theta\right)\right]^{2} \\
r^{2}=\frac{1}{4}\left[\left(S_{h_{\max }}-S_{h_{\max }}\right)^{2}-2 \sigma_{L}\left(S_{H_{\operatorname{mat}}}-S_{h_{\operatorname{mat}}}\right) \cos 2 \theta\right. \\
\left.\quad+\sigma_{L}^{2} \cos ^{2} 2 \theta+\sigma_{i}^{2} \sin ^{2} 2 \theta\right] . \\
\text { Replacing } \cos ^{2} 2 \theta+\sin ^{2} 2 \theta \text { with } 1 \text { gives }
\end{gathered}
$$

$$
r^{2}=\frac{1}{4}\left[\left(S_{H_{\max }}-S_{h_{\operatorname{man}}}\right)^{2}-2 \sigma_{L}\left(S_{H_{\max }}-S_{h_{\min }}\right) \cos 2 \theta+\sigma_{L}^{2}\right]
$$

and dividing through by $\left(S_{H_{\text {max }}}-S_{h_{\text {min }}}\right)^{2}$ yields

$$
\begin{aligned}
& r^{2} /\left(S_{H_{\max }}-S_{h_{\operatorname{mux}}}\right)^{2}=\frac{1}{4}\left[1-\left(2 \sigma_{L} \cos 2 \theta\right) /\left(S_{H_{\max }}-S_{h_{\min }}\right)\right. \\
& \left.\quad+\sigma_{L}^{2} /\left(S_{H_{\max }}-S_{h_{\min }}\right)^{2}\right] .
\end{aligned}
$$

Recall that the stress ratio $k$ is defined as $k=\left(S_{H_{\text {mat }}}\right.$ $\left.S_{h_{\text {Imin }}}\right) / \sigma_{L}$ and substitute

$$
r^{2} /\left(S_{H_{\max }}-S_{h_{\min }}\right)^{2}=\frac{1}{4}\left[1-(2 \cos 2 \theta) / k+1 / k^{2}\right] .
$$

Replacing $r$ from (A5), $r=\frac{1}{2}\left(S_{H} \cdot-S_{h}\right)$ yields

$$
\frac{1}{4}\left(S_{H^{\prime}}-S_{h^{\prime}}\right)^{2} /\left(S_{H_{\max }}-S_{h_{\text {man }}}\right)^{2}=\frac{1}{4}\left[1-(2 \cos 2 \theta) / k+1 / k^{2}\right] \text {. }
$$

Defining $R$ as the ratio of the resultant horizontal stress difference to the regional horizontal stress difference or, equivalently, the ratio of the local to regional horizontal shear stress, we have

$$
R=\left(S_{H^{\prime}}-S_{h^{0}}\right) /\left(S_{H_{\max }}-S_{h_{\operatorname{man}}}\right)
$$

We get the following expression for the normalized resultant horizontal stress differences:

$$
R^{2}=\left[1-(2 \cos 2 \theta) / k+1 / k^{2}\right]
$$

or

$$
R= \pm \sqrt{1-(2 \cos 2 \theta) / k+1 / k^{2}}
$$

Acknowledgments. Helpful reviews by Art McGarr, William D. Stuart, and Donna Jurdy are gratefully acknowledged. We are particularly indebted to Martin Bott for his thorough and thoughtful review (and intuitive insight), which forced us to think very critically about the interaction of the various forces acting in the finite element modeling. This work was supported in part by Nuclear Regulatory Commission funding to M.L.Z., by USGS/NEHRP external and internal research funds to both authors, and by National Science Foundation grant EAR-9219314 to R.M.R. Special thanks to Andreas Weller, diplome student, Karlsruhe University, who provided his Amazonas basin breakout data.

\section{References}

Al-Shukri, H. J., and B. J. Mitchell, Reduced seismic velocities in the source zone of New Madrid earthquakes, Bull. Seismol. Soc. Am., 78 , 1491-1509, 1987a.

Al-Shukri, H. J., and B. J. Mitchell, Three-dimensional velocity variations and their relation to the structure and tectonic evolution of the New Madrid seismic zone, J. Geophys. Res., 92, 6377-6390, $1987 \mathrm{~b}$.

Assumpçāo, M.. The regional intraplate stress field in South America, J. Geophys. Res., 97, 11,889-11,904, 1992.

Assumpção, M.. Focal mechanisms of local earthquakes in SE Brazilian shield, using $S / P$ amplitude ratio, and the regional intraplate stresses, paper presented at Regional Seismological Assembly in South America, Brasilia, Brazil, 1994.

Assumpção, M., and M. Araujo, Effect of the Altiplano-Puna plateau. South America, on the regional intraplate stresses, Tectonophysics. $221,475-496,1993$.

Assumpçào, M., and G. Suarez, Source mechanisms of moderate-size earthquakes and stress orientation in mid-plate South America, Geophys. J.. 92, 253-267, 1988.

Basham, P. W., A Paleozoic-Mesozoic framework for seismic hazard assessment in eastern North America, in Current Research, Part $F$, Pap. Geal. Surv. Can., 89-IF, 45-50, 1989. 
Behrendt. J. C., A. G. Green, W. F. Cannon, D. R. Hutchinison, M. W. Lee, B. Milkereit, W. F. Agena, and C. Spencer, Crustal structure of the Midcontinent rift system: Results from Glimpce deep seismic reflection profiles, Geology, 16, 81-85, 1988.

Brace, W. F., and D. L. Kohlstedt, Limits on lithospheric stress imposed by laboratory experiments, J. Geophys. Res., 85, 6248-6252. 1980.

Byerlee. J. D., Friction of rocks, Pure Apph Geophys., 116, 615-626, 1978.

Cox. J. W., Long axis orientation in elongated boreholes and its correlation with rock stress data, paper presented at Society of Petroleum Well Log Anal. 24th Annual Logging Symposium, 1983.

Ferreira, J., R. Oliveira, M. Takeya, M. Assumpção, L. Camarao and J. Rocha, Focal mechanisms around Potiguar marginal basin, NE Brazil, paper presented at Regional Seismological Assembly in South America, Brasilia, Brazil, 1994.

Fleitout. $L_{\text {., }}$ and $C$. Froidevaux, Tectonics and topography for a lithosphere containing density heterogeneities, Tectonics, 1, 21-56, 1982

Frank, F. C., Plate tectonics, the analogy with glacier flow, and isostasy, in Flow' and Fracture of Rocks, Geophys. Monogr. Ser., vol. 16, edited by H. C. Heard et al., pp. 285-292, AGU, Washington, D. C., 1972.

Grana, J. P., and R. M. Richardson. Tectonic stress within the New Madrid seismic zone, J. Geophys. Res., this issue.

Haimson, B. C., and M. Y. Lee, Hydraulic fracturing tests in the Quimby Granite, and the state of stress in the western midcontinent (abstract), Eos Trans. $A G U, 73(43)$, Fall Meet. Suppl., 559, 1992.

Harper, J. F., On the driving forces of plate tectonics, Geophys. J. $R$ Astron. Soc., 40, 465-474, 1975.

Hildenbrand. T. G., Rift structure of the northern Mississippi embayment from the analysis of gravity and magnetic data, $J$. Geophys. Res., 90, 12,607-12,622, 1985.

Johnston, A., Seismicity of "stable continental interiors," in Earthquakes at North Atlantic Passive Margins: Neotectonics and Postglacial Rebound, edited by S. Gregersen and P. W. Basham, pp. 299-327, Kluwer Acad., Norwell, Mass., 1989.

Johnston, A., and L. R. Kantor, Earthquakes in stable continental crust, Sci. Am., 262, 68-75, 1990.

King. E. R., and I. Zietz, Aeromagnetic study of the midcontinent gravity of the central United States, Geol. Soc. Am. Bull., 82, 21872208, 1971.

Liu, L., M. Zoback, and P. Segall, Rapid intraplate strain accumulation in the New Madrid seismic zone, Science, 257, 1666-1669, 1992.

McGarr, A., On the state of lithospheric stress in the absence of applied tectonic forces, $J$. Geophys. Res., 93, 13,609-13,617, 1988.

Meijer, P. T., and M. J. R. Wortel, The dynamics of motion of the South American plate, J. Geophys. Res., 97, 11,915-11,932, 1992.

Mercier, J. L., M. Sebrier, A. Lavenu, J. Cabrera, O. Bellier, J.-F. Dumont, and J. Machare, Changes in the tectonic regime above a subduction zone of Andean type: The Andes of Peru and Bolivia during the Pliocene-Pleistocene, J. Geophys. Res., 97, 11,945-11,982, 1992.

Mitchell, B. J., O. W. Nuttli, R. B. Herrmann, and W. Stauder, Seismotectonics of the central United States, in Neotectonics of North America, edited by D. B. Slemmons et al., pp. 245-260, Geol. Soc. of Am., Boulder, Colo., 1991.

Mooney, W. D., M. C. Andrews, A. Ginzburg, D. Peters, and R. M. Hamilton, Crustal structure of the northern Mississippi embayment and a comparison with other continental rift zones, Tectonophysics. 94, 327-348, 1983 .
Nunn, J. A., and J. R. Aires, Gravity anumalies and fiexure of the lithosphere at the middle Amazon Basin. Brazil.J. Geophys. Res., 9.3. 415-428, 1988 .

Parsons, B., and F. M. Richter, A relation between driving force and geoid anomaly associated with mid-ocean ridges, Eanh Planet. $S \times r$. Lett., 5l, 445-450, 19801.

Richardson. R. M., Ridge forces, absolute plate motions, and the intraplate stress field. J. Geophys. Res.. 97, 11,739-11.748. 1992.

Richardson, R. M.. and D. D. Coblentz. Stress modeling in the Andes: Constraints on the South American intraplate stress magnitudes. J. Geophys. Res., 99, 22,015-22,025, 1994.

Sibson, R. H., Frictional constraints on thrust, wrench and normal faults, Nuture, 249, 542-544, 1974.

Simpson, R. W., R. C. Jachens, R. J. Blakely, and R. W. Saltus, A new isostatic residual gravity map of the conterminous United States with a discussion on the significance of isostatic residual anomales, J. Geophys. Res., 91, 8348-8372, 1986.

Sonder, L. J., Effects of density contrasts on the orientation of stresses in the lithosphere: Relation to principal stress directions in the Transverse Ranges. California, Tectonics, 9, 761-771, 1990.

Stefanick, M., and D. M. Jurdy, Stress observations and driving forces models for the South American plate, J. Geophys. Res., 97. 11,905$11,914,1992$.

Veloso, J., J. Carvalho, M. Huelsen, L. Gomide, and C. Chimpliganond, Recent seismic activity in the Nova Ponte reservoir area. Brazil, paper presented at Regional Seismological Assembly in South America, Brasilia. Brazil, 1994.

Weller, A., Borehole breakout data constraints on the state of stress in South America, diplome thesis, Karlsruhe Univ., Karlsruhe, Germany, 1993.

Zoback, M. D., and J. H. Healy, Friction. faulting and in situ stress. Ann. Geophys., 2, 689-698. 1984.

Zoback, M. D., and J. H. Healy, In situ stress measurements to $3.5 \mathrm{~km}$ depth in the Cajon Pass scientific research borehole: Implications for the mechanies of crustal faulting, J. Geophys. Res., 97, 5039$5057,1992$.

Zohack. M. D., et al., Upper-crustal strength inferred from stress measurements to $6 \mathrm{~km}$ depth in the KTB borehole, Nature, 365 . 633-635, 1993.

Zoback, M. L., First- and second-order patterns of stress in the lithosphere: The World Stress Map project, J. Geophys. Res.. 97. 11,703$11,728,1992$.

Zoback, M. L., and M. Zoback, State of stress in the conterminous United States, J. Geophys. Res., 85, 6113-6156. 1980.

Zoback, M. L. and M. D. Zoback, Tectonic stress field of the conterminous United States, Mem. Geol. Soc. Am., 172, 523-539, 1989.

R. M. Richardson, Southern Arizona Seismic Observatory, Department of Geosciences, Bldg. 77. University of Arizona, Tucson, AZ 85721-10001. (e-mail: rmr@geo.arizona.edu)

M. L. Zohack, Branch of Seismology. U.S. Geological Survey, 345 Middlefield Road, MS 977, Menlo Park, CA 94025. (e-mail: zoback@andreas.wr.usgs.gov)

(Received November 23, 1994; revised October 11, 1495; accepted October 17, 1995.) 